TESIS DE MAESTRÍA

THE NATURE OF ESPELETIA SPECIES

YAM MELLISSA PINEDA TORRES

DIRECTOR

SANTIAGO MADRIÑÁN

CODIRECTOR

IVÁN JIMÉNEZ

UNIVERSIDAD DE LOS ANDES

FACULTAD DE CIENCIAS

DEPARTAMENTO DE CIENCIAS BIOLÓGICAS

LABORATORIO DE BOTÁNICA Y SISTEMÁTICA

AGOSTO 2019 


\title{
THE NATURE OF ESPELETIA SPECIES
}

\author{
Yam M. Pineda ${ }^{1}$, Andrés J. Cortés ${ }^{2}$, Santiago Madriñán ${ }^{3}$ and Iván Jiménez ${ }^{4}$ \\ ${ }^{3}$ Departamento de Ciencias Biológicas, Universidad de los Andes, Bogotá, Colombia, \\ ${ }^{2}$ Department of Biological and Environmental Sciences, University of Gothenburg, \\ Gothenburg, Sweden, 'Jardín Botánico de Cartagena "Guillermo Piñeres", Turbaco, \\ Colombia, ${ }^{4}$ Center for Conservation and Sustainable Development, Missouri Botanical \\ Garden, St. Louis, MO, USA
}

\section{INTRODUCTION}

Species are often regarded as basic units of biodiversity in ecology, evolution, biogeography and conservation biology, following the presumption that they are real, discrete natural entities (Coyne and Orr 2004; Barraclough and Humphreys 2015). But some biologists, most notoriously botanists, have persistent doubts about the existence of species. They see species as arbitrary divisions of biological diversity that do not necessarily correspond to discrete natural groups of organisms (Levin 1979; Raven 1986; Bachmann 1998). Darwin seemed to have developed a similar view (see Mayr 1982; Mallet 2013): “"...we shall have to treat species in the same manner as those naturalists treat genera, who admit that genera are merely artificial combinations made for convenience. This may not be a cheering prospect, but we shall at least be freed from the vain search for the undiscovered and undiscoverable essence of the term species" (Darwin 1859, page 485). Indeed, Darwin's view about the nature of species may have been largely shaped by interactions with botanists (Mayr 1982). Moreover, botanists could have been overly impressed by a few examples of fuzzy species limits (e.g., blackberries, dandelions and oaks) and wrongly assumed these "botanical horror stories" to be representative of plant species overall (Diamond 1992).

Attempts to empirically solve this controversy about the nature of species would ideally address two related but separate issues. One is whether individual organisms form sympatric, distinct groups in nature (Coyne and Orr 2004; Barraclough and Humphreys 2015). Sympatry is stressed in this context because it implies opportunity for the groups to merge into one (Coyne and Orr 2004), via genetic or demographic exchangeability (Templeton 1989). Thus, sympatric, discrete groups or organisms are widely accepted as evidence of distinct, real units in nature (Mayr 1992; De Queiroz 2007; Mallet 2007, 
2008). The second issue is the degree to which taxonomic classification at the species level accurately reflects distinct groups of individual organisms or constitute arbitrary divisions (Rieseberg et al. 2006). Thus, to address the problem of the nature of species, it is paramount to distinguish the idea of species taxa (i.e., taxonomic divisions at the species level) from the notion of species as biological units in nature (Hey et al. 2003). Species taxa presumably exist in the sense of human-made divisions, documented in taxonomic treatments. And, yet, species may not occur in nature as discrete sympatric groups of individual organisms (Levin 1979; Raven 1986; Bachmann 1998). Moreover, even if species do occur in nature as discrete sympatric groups of individual organisms, human-made taxonomic classification at the species level may not reflect such groups. The first issue above, whether individual organisms form distinct, sympatric groups in nature, may be empirically addressed in the context of multiple, potentially contrasting species definitions (sensu, De Queiroz 1999). In particular, species could be real units in terms of different properties acquired during lineage divergence, include ability to interbreed, ecological divergence and reciprocal monophyly among others. Despite the variety of possible species definitions, there has been enduring interest in the reality of species in terms of two criteria: phenotypic and genome-wide distinctiveness (Dobzhansky 1951; Grant 1957; Mayr 1963; Ehrlich and Raven 1969; Levin 1979; Gould 2002; Coyne and Orr 2004; Rieseberg et al. 2006; Mallet 2013). Several kinds of species may be distinguished when simultaneously considering these two criteria (Fig. 1). One kind includes species that show very little if any phenotypic distinctiveness but differ in allele frequencies across many loci (Fig. 1A). These species are likely reproductively isolated and known as "sibling" (Mayr 1963) or "cryptic" species (Bickford et al. 2007; Fišer et al. 2018; Struck et al. 2018). A second kind of species is characterized by phenotypic distinctiveness in the absence of differences in allele frequencies across most loci (Fig. 1D). "Syngameons" are examples of this second kind of species, where phenotypic distinctiveness is due to few loci, preserved despite interbreeding (Lotsy 1931; Grant 1971; Rieseberg and Burke 2001; Wu 2001) and the basis of meaningful ecological and evolutionary units (Van Valen 1976; Templeton 1989) (Fig. 1D). Yet another kind of species is that of phenotypically distinct lineages that have different allele frequencies throughout the genome. Such species are likely reproductively isolated and, 
thus, are sometimes referred to as "good species" (Fig. 1B, (Templeton 1989; Allmon 2016)). Finally, some species may be characterized by discordant sets of distinct phenotypes and genome-wide allele frequencies (Fig. 1C). In these latter case, phenotypes and genome-wide allele frequencies might reflect contrasting evolutionary histories incorporated into a single species (Doyle 1997; Maddison 1997; Szllosi et al. 2015).

The degree of concordance between distinctiveness in phenotype and genome-wide allele frequencies (Fig. 1) have played a central role in debates about the nature of species (Grant 1957; Ehrlich and Raven 1969; Levin 1979; Diamond 1992; Coyne and Orr 2004; Rieseberg et al. 2006). Yet, there seem to be few empirical studies addressing the controversy by formally testing whether individual organisms form sympatric, distinct groups in nature according to these two criteria (Barraclough and Humphreys 2015; Coyne and Orr 2004), and assessing the correspondence of such groups (if any) to species level taxonomic divisions (but see Rieseberg et al. 2006). The paucity of such studies may partly reflect that methods to formally infer the number of distinct groups in a sample of individuals, with no a priori information about group membership, were developed relatively recently for both phenotypic (Ezard et al. 2010; Cadena et al. 2017) and genome-wide data (Pritchard et al. 2000; Huelsenbeck and Andolfatto 2007; Raj et al. 2014; Verity and Nichols 2016; Cadena et al. 2017). Thus, until recently, there was little empirical guidance for studies attempting to formally assess the nature of species in terms of concordance between distinctiveness in phenotype and genome-wide allele frequencies. But even outstanding species delimitation studies, employing state-of-the-art methods (e.g.(Spriggs et al. 2019), are commonly based on geographically sparse sampling, characterized by well-separated collection localities and few specimens per locality. Such sampling has been traditionally used to accumulate invaluable collections in natural history museums (ter Steege et al. 2011) required for global taxonomic assessments of monophyletic clades. However, geographically sparse sampling is often insufficient to rigorously determine if individual organisms form distinct, sympatric groups in terms of phenotypes and genome-wide allele frequencies. Consequently, the debate about the nature of species remains unsatisfactorily addressed by empirical studies. Yet, understanding such nature is a major and long standing issue in evolutionary 
biology (Barraclough et al. 2003; Coyne and Orr 2004; Rieseberg et al. 2006;

Barraclough and Humphreys 2015) with significant implications for basic and applied fields in biology (Richards 2010; Sigwart 2018).

Here we contribute to empirically address the debate about the nature of species by providing a carefully worked example, characterized by geographically dense sampling of organisms to determine whether individual organisms form sympatric, distinct groups in nature. We used formal approaches to i) infer sympatric groups of organisms in terms of phenotype and genome-wide allele frequencies, ii) measure the degree of concordance between distinctiveness in phenotype and genome-wide allele frequencies (Fig. 1), and iii) the concordance between species taxa (i.e., taxonomic divisions at the species level) and distinctiveness in phenotype and genome-wide allele frequencies. We are unaware of empirical studies about the nature of species that employ these approaches on a geographically dense sampling of individual organisms.

We focused on Espeletia, a genus of plants endemic to the northern Andes (Monasterio and Sarmiento 1991; Rauscher 2002; Cuatrecasas 2013; Diazgranados and Barber 2017) and often dominant in high elevation ecosystems known as "páramos" (Ramsay and Oxley 1997). This genus appears to have undergone and very rapid radiation starting around 2.7 Ma (Madrinán et al. 2013; Pouchon et al. 2018). Espeletia species are suspected to commonly produce inter-specific hybrids, even between distantly related species (Pouchon et al. 2018), and, nevertheless, maintain phenotypic and ecological integrity (Berry et al. 1988; Diazgranados 2012; Cuatrecasas 2013; Diazgranados and Barber 2017). In one of the (two) prefaces of the most recent Espeletia monograph (Cuatrecasas 2013), Harold Robinson wrote: "The recent origin, the high specialization and the complex structure of the often large plants, added to the few barriers to hybridization in addition to geography, even at the intergeneric level, presented many complications for the monographic study." Indeed, along with other plant genera (e.g., oaks, irises, pines, aspen, eucalyptus, dandelions and blackberries (Lenz 1959; Van Valen 1976; Sutton et al. 1991; Alice et al. 2001; Field et al. 2009; Cronk and Suarez-Gonzalez 2018)), Espeletia may be a "botanical horror story" (Diamond 1992) from which we may learn much about the nature of plant species. 


\section{MATERIALS AND METHODS}

\section{Study region and taxa}

We studied plants of the genus Espeletia occurring in the páramo de Sumapaz. This páramo encompasses $1780 \mathrm{~km}^{2}$ in the Cordillera Oriental of the Colombian Andes, south of Bogotá, and includes the high elevation areas of Parque Nacional Sumapaz. Annual average temperature varies spatially between $2^{\circ}$ and $10^{\circ} \mathrm{C}$ and annual rainfall between 500 and $2000 \mathrm{~mm}$. According to the most recent Espeletia monograph (Cuatrecasas 2013), seven Espeletia species occur in the páramo de Sumapaz: Espeletia argentea Humb. \& Bonpl., Espeletia cabrerensis Cuatrec., Espeletia grandiflora H. \& B., Espeletia killipii Cuatrec., Espeletia miradorensis (Cuatrec.) Cuatrec., Espeletia summapacis Cuatrec. and Espeletia tapirophila Cuatrec. The monograph also mentions infra-specific taxa occurring in the páramo de Sumapaz for three of the species: Espeletia argentea fma. phaneractis (S.F.Blake) A.C.Sm., E. grandiflora spp. grandiflora var. attenuata Cuatrec., E. grandiflora spp. subnivalis Cuatrec. and Espeletia killipii var. chiscana Cuatrec.

\section{Specimen collection}

To sample Espeletia species we defined the limit of the páramo de Sumapaz as the 3,000 m elevation isocline, based on the Aster digital elevation model with $30 \mathrm{~m}$ resolution (https://asterweb.jpl.nasa.gov/gdem.asp). Thus defined, the páramo de Sumapaz was divided into quadrants of $2 \times 2 \mathrm{~km}$. We sampled 34 of these quadrants by randomly choosing two $30 \times 30 \mathrm{~m}$ grid cells (of the Aster digital elevation model) in each band of $100 \mathrm{~m}$ elevation (Fig 2). We sampled a total of 219 grid cells of $30 \times 30 \mathrm{~m}$. In each grid cell we collected one specimen of each seemingly different phenotype. Additionally, we also collected specimens opportunistically to further document the occurrence of different phenotypes across the páramo de Sumapaz. In total we collected 540 specimens of reproductive Espeletia plants, all deposited in triplicate at the herbarium of the Jardín Botánico de Bogotá (JBB). 


\section{Phenotypic distinctiveness}

\section{Morphological characters}

We measured thirteen morphological characters to measure phenotypic distinctiveness among Espeletia species from the páramo de Sumapaz (Table 1). Except perimeter of the synflorescence axis, all these characters were discussed by Cuatrecasas (2013) as useful traits to delimit Espeletia species from the páramo de Sumapaz. We additionally included the perimeter of the synflorescence axis because in the field this character seemed useful to distinguish some putative species.

Whenever possible, we measured all morphological characters above in each of the 540 specimens we collected. Additionally, we measured as many of the morphological characters as possible in each of 156 specimens from páramo de Sumapaz, or from taxa known to occur there, that were collected by other researchers and deposited in the Herbario Nacional Colombiano (COL), at the Instituto de Ciencias Naturales, Universidad Nacional de Colombia. Out of these 156 specimens, 127 were explicitly mentioned in the Espeletia monograph by Cuatrecasas (2013), including types for all but one (Espeletia argentea) species taxa that, according to Cuatrecasas (2013), occur in the páramo de Sumapaz. When it was possible, each one of the morphological characters was measured in three separate structures per specimen (as mentioned before, specimens were collected in triplicates), and analyses were based on average values per specimen to account for intra-individual variation (Hou and Li 2010; Lim et al. 2012). The length of synflorescence axis was measured in the field to the nearest centimeter. All other measurements were done in the herbarium after the specimens were dried. To measure leaf blade length and width we took photographs on a standard background including a millimeter ruler and then processed them using the measure tool in the Image $J$ program (Schindelin et al. 2012). Capitulum diameter, length and width of the corolla of the flowers of the disc, length of the corolla of the flowers of the ray, and length of the tubes of the disc were measured with a three-digit precision gauge.

\section{Estimating morphological groups}

To estimate the number phenotypic groups among the measured Espeletia specimens, as well as the assignment of specimens to such groups, we used the R package Mclust 5.0 
(Scrucca et al. 2016) to fit normal mixture models (NMM, McLachlan and Peel 2000) to our morphological data. NMMs conceptualize phenotypic variation as a mixture of different normal distributions. This model assumes polygenic inheritance and random pairing; under these assumptions, gene frequencies would be close to Hardy-Weinberg equilibrium, two or more loci would be near linkage equilibrium, and phenotypic variation among individuals of a single species would tend to be normally distributed (Templeton 2006; Cadena et al. 2017). The parameters of a NMM (e.g., means, variances and covariances) describe each morphological group as a (possibly multivariate) Gaussian distribution and can be estimated using maximum likelihood from data on phenotypic measurements, without a priori knowledge of species limits, using the algorithm of expectation-maximization (McLachlan and Krishnan 2008).

We used the Bayesian Information Criterion (BIC, Schwartz 1978) to estimate the number of phenotypic groups among the specimens we measured, as well as the location and spread of such groups in morphological space. BIC measures empirical support for NMMs that differ in parameter values, including number of morphological groups (Fraley and Raftery 2002). We fitted NMMs that covered a wide range of the parameter defining the number of morphological groups, at one extreme some NMMs assumed a single morphological group and at the other up to ten groups. This latter number of groups is three more than the number of species expected in the study according to Cuatrecasas (2013). To define the morphological space to be considered in the MMNs, we first rotated the data on thirteen morphological characters (Table 1) using a principal component analysis on the covariance matrix of the natural logarithm of the original data. One of these characters (i.e., pairs of sterile leaves per synflorescence) took on zero values, so we added one to this variable before the logarithm transformation. We used $\mathrm{R}$ package Clustvarsel (Scrucca and Raftery 2018) to reduce the dimensionality of the data by selecting the most useful set of principal components for the discrimination of groups in NMMs, without a priori information about the groups (Raftery and Dean 2006; Maugis et al. 2009; Cadena et al. 2017). 


\section{Genome-wide allele frequencies distinctiveness \\ DNA Extraction and Genotyping-by-Sequencing}

Genomic DNA was extracted using the QIAGEN DNeasy Plant Mini Kit (QIAGEN, Germany). DNA concentration was quantified in R Qubit dsDNA HS Fluorometer (Life Technologies, Sweden). One 96-plex genotyping-by-sequencing libraries were performed with MsII digestions according to (Elshire et al. 2011) and sequenced at LGC Genomics (Berlin, Germany). Readings were aligned following Cortés et al. (2018) using a cluster of 283 Espeletia samples, built with 192 samples from that study in addition to 96 samples (specimens) from this study. Filtering of variants was done using a GBS-specific rule set with $>5$ read count for a locus, $>5 \%$ minimum allele frequency across all samples, and an observation of genotype frequency of at least $80 \%$. This filtering reduced the initial sample of 99 specimens to 77 . The filtered dataset was inspected with TASSEL v. 3.0 (Glaubitz et al. 2014), resulting in a final set of 2,098 single nucleotide polymorphisms (SNPs).

\section{Estimating groups according to genome-wide allele frequencies}

To infer the number of groups according to genome-wide allele frequencies among genotyped Espeletia specimens, and assign specimens to such groups, we implemented ancestry models in R Maverick package in R 3.3.1. (Verity and Nichols 2016). These models assume that groups are in the Hardy Weinberg equilibrium with their own set of allele frequencies and that all loci are in linkage equilibrium (Pritchard et al. 2000). Maverick uses thermodynamic integration to estimate the number of groups, based on the posterior probability of models, given the data and a prior distribution of model parameters (Verity and Nichols 2016). This method distinguishes Maverick from other approaches that rely on less formal, heuristic methods to evaluate the number of groups according to genome-wide allele frequencies.

We evaluated models postulating a wide range of number of groups among Espeletia specimens, from a single group up to ten. Again, the latter number is three groups more than expected by the number of species occurring in the páramo de Sumapaz according to Cuatrecasas (2013). All models allowed admixture. 


\section{Species taxa}

To determine the extent to which species taxa corresponded to phenotypic groups and groups based on genome-wide allele frequencies, we assigned specimens to species taxa based detailed descriptions in Cuatrecasas (2013). In particular, for all species taxa expected to occur in Sumapaz, according to Cuatrecasas (2013), we obtained the maximum and minimum values for all the 13 characters in Table 1 except but one perimeter of the synflorescence axis. As already mention, this character was not considered by Cuatrecasas (2013). Then, for each specimen in our sample, we determined if the measured values for the 12 characters fell within the ranges of each taxa species. We assigned a specimen to a species taxa if the measurements for all 12 characters fell within the respective ranges provided by Cuatrecasas (2013).

\section{Concordance between groups defined by phenotype, genome-wide allele frequencies and species taxa}

To estimate the degree of concordance between the groups of specimens defined according to phenotypes, genome-wide allele frequencies and species taxa we used Goodman and Kruskal tau statistic (GKtau), as implemented in R package 'GoodmanKruskal' version 0.0.2 (Pearson 2016). GKtau is a measure of asymmetric association between two classifications. Asymmetry in these kind of association may arise because one classification, say based on phenotypic characters, may predict the assignment of individuals in another classification better than the latter may predict the former (Pearson 2016). Therefore, we performed two tests to gauge concordance between a given pair of classifications. The first examines the degree to which the assignment of specimens to groups according to the first classification (e.g., based on phenotype) predicts the assignment of specimens to groups according to the second classification (e.g., based on genome-wide allele frequencies). The other tests the degree to which specimen assignment to groups according to the second classification predicts specimen assignment according to the first classification. We evaluated the statistical significance of both tests using 1,000 iterations of a null model that randomized the assignment of specimens to groups in one of the two classifications being compared. We We calculated GKtau for each iteration of the null model and thus constructed a null distribution of 
1,000 GKtau values. We estimated p-values for each test as the fraction of Gktau values in the null distribution that were at least as extreme as the observed GKtau value.

\section{Sympatry}

We adopted an operational definition of sympatry based on a concept reflecting both gene flow and geography (Mallet et al. 2009). According to this concept, populations are sympatric when they have geographic distributions within the normal cruising range of individuals of each other (Mayr 1947), so that gametes of individuals are physically capable of encountering one another with moderately high frequency (Futuyma and Mayer 1980). The normal cruising range of individuals is determined by the distribution of distances between the sites of birth and breeding of individual organisms (Mallet et al. 2009). Thus, both pollen and seed dispersal are relevant to this operational definition of sympatry, although in Espeletia seed dispersal is thought to be fairly limited (Berry and Calvo 1989; Diazgranados 2012; but see Gallego Maya and Bonilla Gómez 2016). In sharp contrast, the pollen of Espeletia is thought to travel considerable distances via bumblebees (genus Bombus) and, potentially, hummingbirds (Fagua and Gonzalez 2007); except in some species that seem to be pollinated by wind (Berry and Calvo 1989; ).. Bumblebees home back to their nests from places $9.8 \mathrm{~km}$ away (Goulson and Stout 2001) and regularly perform flights covering $>1 \mathrm{~km}$ (Greenleaf et al. 2007; Pope and Jha 2018). Thus, we considered inter-group distances $<1 \mathrm{~km}$ as definitively small enough for sympatry and inter-group distances $<5 \mathrm{~km}$ as likely small enough for sympatry. Accordingly, to estimate the degree of sympatry between a given pair of groups (phenotypic or defined by genome-wide allele frequencies), we measured the geographic distance between each specimen and the nearest specimen that did not belong to the same group. We examined the resulting distribution of inter-group distances to determine if groups were separated by $<1 \mathrm{~km},<5 \mathrm{~km}$ or longer distances.

\section{RESULTS}

\section{Phenotypic distinctiveness}

The morphological analysis included only 295 out of 696 specimens measured in this study, because several specimens were missing values for at least one of the 13 characters 
studied (Table 1). This was mainly due to the fact that not all specimens exhibited flowers anthesis.

Reducing the dimensionality of the data from a total of 13 principal components to nine $(1,2,3,5,6,7,8,9,10)$ or twelve (1 through 12$)$ seem to be equally useful for the discrimination of groups in normal mixture models (NMMs). The reduction to nine axes had the highest empirical support when implementing the procedure for reduction of dimensionality (Clustvarsel, see Methods) based on a forward algorithmic search of principal components, whereby axes (i.e., principal components) were progressively added to NMMs. In contrast, the reduction to twelve axes had the highest empirical support when using a backward algorithmic search that begins with all 13 available axes and progressively discards axes to examine NMMs with lower dimensionality. Although NMMs based on these two alternatives (nine and twelve principal components) differed in details regarding the location and spread of groups in morphological space as well as the assignment of specimens to groups, both models yielded the same results in terms of the number of sympatric morphological groups, concordance with other classifications (based on genome-wide allele frequencies and species taxa). Therefore, given that the main conclusions were insensitive to the choice between the NMM with nine and twelve principal components, for simplicity here we focus on the former model.

We found support for the existence distinct phenotypic groups among the Espeletia specimens from páramo de Sumapaz. In particular, the best NMM identified seven morphological groups and had substantially more empirical support than models assuming 1-6 and 8-10 groups ( $\triangle \mathrm{BIC}>10$, Fig. 3A). In this best model, the morphogroups appear to be fairly distinct, beacuse assignment of specimens to morphogroups entailed little uncertainty. For all but three specimens in the analysis, the probability of assignment to their corresponding morphogroup exceeded 0.9. Put aother way, in a probability scale, assignment uncertainty exceeded 0.1 in only three specimens out of 296.

In the best model, four groups were easily distinguished in the morphological space defined by the first two principal components, mainly determined by four characters: number of capitula per synflorescence, number of sterile leaves per synflorescense, 
length of the cyma peduncle and sterile phyllary width (Fig. 4A). At one extreme of this space, morphogroup 1 had the narrower sterile phyllaries and shortest cyma peduncles (lower right in Fig. 5A). At another extreme, morphogroup 4 was characterized by the widest sterile phyllaries, many capitula for synflorescence and several pairs of sterile leaves per synflorescence (central upper part in Fig. 5A). Finally, morphogroups 6 and 7 were distinguished from the rest by having long cyme peduncles, few capitula per synflorescence and no sterile leaves along the synflorescence (extre left in Fig. 5A). These last two morphogroups (6 and 7) differed from each other most clearly in terms of the width of sterile phyllaries. The three remaining morphogroups were most easily distinguished in the morphological space defined by principal components 2 and 3 , mainly determined by leaf balde width, number of capitula per synflorescense, number of sterile leaves per synflorescence, sterily phyllary width and length of the tubes of the flowers in the disc (Fig. 4C). In these space, morphogroups 3, 5 and 2 were located along a gradient of increasing values for the the number of sterile leaves per synflorescence (Fig. 5C).

\section{Distinctiveness in genome-wide allele frequencies}

We found support for the existence of more than one genomic group among the Espeletia plants we sampled from the páramo de Sumapaz. In particular, an ancestry model with three groups had the highest empirical support, with posterior probability of almost one (Fig. 3-B). In this best ancestry model, however, the genomic groups did not seem particularly distinct. One of these groups had only six specimens, all with a relatively low proportion of alleles from other groups (Fig. 7A). However, the other two groups were much larger (32 and 39 specimens) and included specimens with fairly high proportions of mixed ancestry. Indeed, in both these groups specimens with more than $10 \%$ admixture were nearly half the group (19 and 21, respectively), and fairly high values of admixture (>20\%) were not uncommon (Fig. 7A).

\section{Species taxa}

Our procedure to assign species to specimens resulted in only one specimen being assigned to any species taxa, out of a total of 296 specimens with data for all 12 relevant measurements (i.e., all characters in Table 1 except perimeter of the synflorescence axis). 
In particular, one specimen was assigned to Espeletia killipii Cuatrec. All other specimens fell outside the ranges specified by Cuatrecasas (2013) for the species expected to occur in the páramo de Sumapaz. This remarkable result, whereby all but one of the Espeletia specimens in our sample could not be formally assigned to any species taxa, meant that it was not possible to apply a test of concordance between species taxa and groups defined by phenotypic distinctiveness and genome-wide allele frequencies. Such concordance was null, because the morphological space defining species taxa (according to Cuatrecasas 2013) was nearly void of specimens.

\section{Concordance between distinctiveness in phenotype and genome-wide allele frequencies}

The analysis of concordance between the classifications based on two different operational criteria only included 46 specimens, because several specimens included in the genetic analysis were not in anthesis and, therefore, did not enter the morphological analysis. While the association between the classifications was not very strong, it was statistically significant in one direction. The groups according to allele frequencies were not predictive of specimen assignment to phenotypic group (GKtau $=0.147, \mathrm{p}$-value $>$ $0.001 \mathrm{Fig}$. S1). On the other hand, phenotypic groups did predict to some degree the assignment of specimens to groups based on allelic frequencies (GKtau $=0.382$, p-value $<0.001$ Fig. S2). Thus, knowledge of phenotypic groups conferred significant but poor ability to predict group based on genome-wide allele frequencies (GKtau ranges from zero to one). This weak concordance seems mainly due to the complete inclusion of morphogroups 4 and 7 into single genomic groups, and to the complete inclusion of one genomic group within morphogroup 1 (Fig. 7A and B). However, five out of seven morphogroups straddled two genomic groups, and two out of three genomic groups included multiple morphogroups (Fig S2).

\section{Sympatry}

All the seven morphological groups seemed largely sympatric. Under the assumption that inter-group geographic distances $\leq 5 \mathrm{~km}$ allowed gamete exchange via pollen dispersal by bumblebees, all pairs of morphogroups were sympatric, because all inter-group geographic distances were less than $2 \mathrm{~km}$. Moreover, out of 21 morphogroup pairs only 
five exceeded $1 \mathrm{~km}$ (Fig. 6). Therefore, under the assumption that geographic distances $\leq$ $1 \mathrm{~km}$ imply sympatry, six morphogroups $(1,2,3,5,6$ and 7$)$ were sympatric with at least four other morphogroups and one morphogroup (4) was sympatric with two other morphogroups (Fig. 6, S3).

The groups according to the allele frequencies are sympatric, given that all inter-group distances were $\leq 1 \mathrm{~km}$ (Fig. 8, S4)

\section{DISCUSSION}

To our surprise, we found that species taxa delimited by Cuatrecasas (2013) were mostly empty in the sense that they contained only one of the 296 Espeletia specimens from Sumapaz in our analyses. In other words, we did not find the species taxa of Cuatrecasas (2013) in nature. However, analysis of data on thirteen morphological characters did reveal fairly distinct, sympatric phenotypic groups among the Espeletia from Sumapaz. On the other hand, analysis of genome-wide allelic frequencies indicated somewhat indistinct, sympatric groups with seemingly high levels of admixture among the Espeletia from Sumapaz. These phenotypic and genomic groups were only weakly concordant. Therefore, among the various possible scenarios regarding the nature of species, our data is only consistent with those in Fig. 1C. The Espeletia from Sumapaz seem to form discordant sets of distinct phenotypes and seemingly less distinct groups of genome-wide allele frequencies, suggesting that phenotypes and genome-wide allele frequencies reflect contrasting evolutionary histories incorporated into a single species. Next we explore implications of these results and potential caveats in our analyses.

Normal mixture models (NMMs) revealed distinct, sympatric morphological groups, which suggests the existence of seven, non-cryptic Espeletia species in Sumapaz, thus ruling out scenarios depicted in Fig1A and E. This conclusion is based on the assumptions needed to apply NMMs to species delimitation based on phenotypic characters (Cadena et al. 2017), including polygenic inheritance. We are not aware of studies of the genetic architecture of morphological characters in Espeletia. However, studies of quantitative trait loci (QTL) in confamilial species suggests that morphological characters (including some in Table 1) are determined by QTL of small effects (relative to the variance of inter-specific backcross populations, Lexer et al. 2005), as expected for 
polygenic inheritance. Two additional assumptions implicit in the application of NMMs to our context are that morphological groups do not reflect ontogenetic variation or phenotypic plasticity (Cadena et al. 2017). Given that all specimens included in the analysis were adult reproductive plants, we expect only negligible ontogenetic effects. Also, morphogroups seemed to share environments, at least broadly defined, as suggested by extensive sympatry (Fig. 6 and Fig. S3). In sum, the assumptions required by the application of NMMs seem to be reasonable for our study system.

We found evidence of three sympatric groups of Espeletia specimens from Sumapaz, characterized by different allelic frequencies across the genome. However, in contrast to the morphological groups, these genomic groups seemed indistinct and characterized by high levels of admixture. Moreover, the admixture proportions of different specimens seem to form a gradient from north to south (Fig. 7C), suggesting a pattern of isolation by distance. Yet, the ancestry models we used assume Hardy-Weinberg equilibrium and linkage equilibrium within groups (Pritchard et al. 2000). These models are likely a useful but rough approximation to reality, and it may be unwise to place much emphasis on any single value for the number of genomic groups (in our case 3). It may be more useful to consider the entire distribution of posterior probabilities for the number of genomic groups (Verity and Nichols 2016). Nonetheless, in our case the posterior distribution for the number of groups takes a value close to one for three groups and close to zero for all other values (Fig. 3-B), by which we conclude that there is strong support for three genomic groups. However, these groups seem indistinct due to admixture and may partly reflect isolation by distance across all Espeletia from Sumapaz.

The weak concordance between phenotypic and genomic groups suggests that the nature of Espeletia species in Sumapaz resembles that depicted in Figure 1C. However, the genomic groups are poorly differentiated (Fig. 7A) and the geographic distribution of admixture proportions suggests an overall effect of isolation by distance (Fig. 7C). Therefore, the nature of Espeletia species in Sumapaz may also be similar to the model depicted in Fig 1D, a syngameon. In both cases (Fig. $1 \mathrm{C}$ and D) phenotypic but and genetic distinctiveness reflect contrasting evolutionary histories (Doyle 1997; Maddison 1997; Szllosi et al. 2015). This lack of agreement may be due to the fact that a general scan of the allele frequencies across the genome may not represent small and atypical 
parts of the genome that determine phenotypic distinction, as seems to be the case on oaks (Hipp et al. 2019). These results are in line with previous studies that inferred hybridization between distantly related taxa (Pouchon et al. 2018), measured high interspecific crossability (Berry et al. 1988) and observed pupative hybrids between several species pairs (Cuatrecasas 2013; Diazgranados and Barber 2017).

We did not find the species taxa described in the most recent monograph of Espeletia (Cuatrecasas 2013) for the páramo de Sumapaz. This result suggests that species taxa are not even arbitrary divisions of biological diversity, as proposed by botanists (Levin 1979; Raven 1986; Bachmann 1998) and suggested by Darwin (1859). Far more disconcerting, species taxa in Espeletia appear to largely miss biological diversity, delineating mostly empty phenotypic space. We wonder if this result is unique to our study taxa and region. We note, however, that formal, specimen-based exploration of the multidimensional phenotypic space proposed in the taxonomic monographs is rarely carried out. In this study we provide a simple example of how such exploration may be accomplished. This is no small matter, given that species are considered basic units of biodiversity in ecology, evolution, biogeography and conservation biology (Coyne and Orr 2004, Barraclough and Humphreys 2015, Richards 2010; Sigwart 2018). In any case, our findings regarding species taxa strongly suggest the need to revise species limits in Espeletia, in addition to the taxonomic changes above the species level suggested by Pouchon et Al. 2018).

\section{ACKNOWLEDGMENTS}

We thank the Jardín Botánico Bogotá (JBB) for its collaboration in processing the material and the Herbarium of the Universidad Nacional (COL) for allowing us to review the collection. We thank Parques Nacionales Naturales for allowing us to work in the Páramo de Sumapaz national park. We thank the Ballón de Alta Montaña No. 1 for hosting and collaborating on more than five occasions. We thank Daniela Camacho, Alvaro Mariño, David Quinche, Julián Forero and Juan Martinez for the work in the field. We thank Cristian Tibabisco, Erika Benavides, Moises Penagos \& family, Paola Medina and B.Viviana Rodríguez for all their collaboration provided in the project. We thank Nat-Geo and the Fondo de Investigaciones de la Facultad de Ciencias of the 
Universidad de los Andes for the financing granted. We would also like to thank Catalina Gonzalez and James Richardson for their evaluation of the work.

\section{REFERENCES}

Alice L.A., Eriksson T., Eriksen B., Campbell C.S. 2001. Hybridization and Gene Flow between Distantly Related Species of Rubus (Rosaceae): Evidence from Nuclear Ribosomal DNA Internal Transcribed Spacer Region Sequences. Syst. Bot. 26:769778.

Allmon W.D. 2016. Studying Species in the Fossil Record : A Review and Recommendations for a More Unified Approach. W.D. Allmon, M.M. Yacobucci (eds.). Species Speciat. Foss. Rec. Univ. Chicago Press.:59-120.

Bachmann K. 1998. Species as units of diversity: an outdated concept. Theory Biosci. 117:213-230.

Barraclough T., Birkyly W., Burt A. 2003. Diversification in Sexual and Asexual Organisms. Evolution (N. Y). 9:2166-2172.

Barraclough T.G., Humphreys A.M. 2015. The evolutionary reality of species and higher taxa in plants: A survey of post-modern opinion and evidence. New Phytol. 207:291-296.

Berry P., Beaujon S., Calvo R. 1988. La hibridización en la evolución de los frailejones (Espeletia, Asteraceae). Ecotropicos. 1:11-24.

Berry P.E., Calvo R.N. 1989. Wind Pollination, Self-Incompatibility , and Altitudinal Shifts in Pollination Systems in the High Andean genus Espeletia (Asteraceae ). Am. J. Bot. 76:1602-1614.

Bickford D., Lohman D.J., Sodhi N.S., Ng P.K.L., Meier R., Winker K., Ingram K.K., Das I. 2007. Cryptic species as a window on diversity and conservation. Trends Ecol. Evol.:22, 148-155.

Cadena C.D., Zapata F., Jiménez I. 2017. Issues and Perspectives in Species Delimitation using Phenotypic Data: Atlantean Evolution in Darwin's Finches. Syst. Biol. 67:181-194. 
Cortés A.J., Garzón L.N., Valencia J.B., Madriñán S. 2018. On the Causes of Rapid Diversification in the Páramos: Isolation by Ecology and Genomic Divergence in Espeletia. Front. Plant Sci. 9:1-17.

Coyne J.A., Orr H.A. 2004. Speciation. Sinauer Associates, Inc.,Publishers Sunderland, Massachusetts U.S.A: .

Cronk Q.C., Suarez-Gonzalez A. 2018. The role of interspecific hybridization in adaptive potential at range margins. Mol. Ecol. 27:4653-4656.

Cuatrecasas J. 2013. A Systematic Study of the Subtribe Espeletiinae (Heliantheae, Asteraceae). Volume 107; The New York Botanical Garden Press: .

Darwin C. 1859. The origin of species. Routledge: .

Diamond J.M. 1992. Horrible plant species. Nature. 360:627-628.

Diazgranados M. 2012. A nomenclator for the frailejones (Espeletiinae Cuatrec., Asteraceae). PhytoKeys. 16:1-52.

Diazgranados M., Barber J.C. 2017. Geography shapes the phylogeny of frailejones (Espeletiinae Cuatrec., Asteraceae): a remarkable example of recent rapid radiation in sky islands. PeerJ. 5:e2968.

Dobzhansky T. 1951. Genetics and the Origin of Species. 3rd edition, New York: Columbia Univ. Press: .

Doyle J. 1997. Trees Within Trees : Genes and Species, Molecules and Morphology. Syst. Biol. 46:537-553.

Ehrlich P.R., Raven P.H. 1969. Differentiation of Populations Published. Science (80-. ). 165:1228-1232.

Elshire R.J., Glaubitz J.C., Sun Q., Poland J.A., Kawamoto K., Buckler E.S., Mitchell S.E. 2011. A robust, simple genotyping-by-sequencing (GBS) approach for high diversity species. PLoS One. 6:1-10.

Ezard T.H., Pearson P.N., Purvis A. 2010. Algorithmic approaches to aid species' delimitation in multidimensional morphospace. BMC Evol. Biol. 10:1-11. 
Fagua J.C., Gonzalez V.H. 2007. Growth rates, reproductive phenology, and pollination ecology of espeletia grandiflora (Asteraceae), a giant Andean caulescent rosette. Plant Biol. 9:127-135.

Field D.L., Ayre D.J., Whelan R.J., Young A.G. 2009. Molecular and morphological evidence of natural interspecific hybridization between the uncommon Eucalyptus aggregata and the widespread E. rubida and E. viminalis. Conserv. Genet. 10:881896.

Fišer C., Robinson C.T., Malard F. 2018. Cryptic species as a window into the paradigm shift of the species concept. Mol. Ecol. 27:613-635.

Fraley C., Raftery A.E. 2002. Model-Based Clustering, Discriminant Analysis, and Density Estimation. J. Am. Stat. Assoc. 97:611-631.

Futuyma D.J., Mayer G.C. 1980. Non-Allopatric Speciation in Animals. Syst. Zool. 29:254-271.

Gallego Maya A., Bonilla Gómez M. 2016. Caracterización de Micrositios para el establecimiento de plántulas de Espeletia uribei (Asteraceae). Acta Biológica Colomb. 21:387-398.

Glaubitz J.C., Casstevens T.M., Lu F., Harriman J., Elshire R.J., Sun Q., Buckler E.S. 2014. TASSEL-GBS: A high capacity genotyping by sequencing analysis pipeline. PLoS One. 9:e90346. doi:10.1371/journal.pone.0090346.

Gould S.. 2002. The Structure of Evolutionary Theory. Harvard University Press: .

Goulson D., Stout J. 2001. Homing ability of the bumblebee Bombus terrestris (Hymenoptera: Apidae). Sciences (New. York). 15:199-207.

Grant V. 1957. The plant species in theory and practice. Species Probl. (ed. Mayr, E.). Am. Assoc. Adv. Sci. Washint.38-90.

Grant V. 1971. Plant Speciation. Verne Grant. Columbia University Press, New York, 1971. xii, 436 pp., illus. \$15. Columbia Univ. Press. New York. Xii:436.

Greenleaf S.S., Williams N.M., Winfree R., Kremen C. 2007. Bee foraging ranges and their relationship to body size. Oecologia. 153:589-596. 
Hey J., Waples R.S., Arnold M.L., Butlin R.K., Harrison R.G. 2003. Understanding and confronting species uncertainty in biology and conservation. Trends Ecol. Evol. 18:597-603.

Hipp A., Whittemore A., Garner M., Guichoux E., Hahn M., Fitzek E., Cavender-bares J., Gugger P.F., Manos P.S., Pearse I.S., Cannon C.H. 2019. Conserved DNA polymorphisms distinguish species in the eastern North American white oak syngameon: Insights from an 80-SNP oak DNA genotyping toolkit. bioRxiv. 602573.

Hou Z., Li S.H. 2010. Intraspecific or interspecific variation: Delimitation of species boundaries within the genus Gammarus (Crustacea, Amphipoda, Gammaridae), with description of four new species. Zool. J. Linn. Soc. 160:215-253.

Huelsenbeck J.P., Andolfatto P. 2007. Inference of population structure under a Dirichlet process model. Genetics. 175:1787-1802.

Lenz L.W. 1959. Hybridization and speciation in Pacific Coast Irises. Aliso. 4:237-309.

Levin D.A. 1979. The nature of plant species: Science. 204:381-384.

Lexer, C., Rosenthal, D.M., Raymond, O., Donovan, L.A. and Rieseberg, L.H., 2005. Genetics of species differences in the wild annual sunflowers, Helianthus annuus and H. petiolaris. Genetics, 169,4:2225-2239.

Lim G.S., Balke M., Meier R. 2012. Determining species boundaries in a world full of rarity: Singletons, species delimitation methods. Syst. Biol. 61:165-169.

Lotsy J.P. 1931. On the species of the taxonomist in its relation to evolution. Genetica. $13: 1-16$.

Maddison W.P. 1997. Gene trees in species trees. Syst. Biol. 46:523-536.

Madriñán S., Cortés A.J., Richardson J.E. 2013. Páramo is the world's fastest evolving and coolest biodiversity hotspot. Front. Genet. 4:1-7.

Mallet J. 2007. Concepts of Species. Encycl. Biodivers.:1-15.

Mallet J. 2008. Hybridization, ecological races and the nature of species: empirical evidence for the ease of speciation. Proc. R. Soc. 363:2971-2986. 
Mallet J. 2013. Species, Concept of. Encycl. Biodivers. 679:9-15.

Mallet J., Meyer A., Nosil P., Feder J.L. 2009. Space, sympatry and speciation. J. Evol. Biol. 22:2332-2341.

Maugis C., Celeux G., Martin-Magniette M.L. 2009. Variable selection for clustering with gaussian mixture models. Biometrics. 65:701-709.

Mayr E. 1947. Ecological Factors in Speciation. Evolution (N. Y). 1:263-288.

Mayr E. 1963. Animal Species and Evolution. Belkn. Press Harvard Univ. Press. Cambridge,

Mayr E. 1982. The Growth of Biological Thought Diversity, Evolution, and Inheritance. . Mayr E. 1992. A local flora and the biological species concept. Am. J. Bot. 79:222-238. McLachlan G., Peel D. 2000. Finite Mixture Models. A wile-Interscience Publication, John wiley \& Sons, inc. New York: .

McLachlan G.J., Krishnan T. 2008. The EM Algorithm and Extensions. .

Monasterio M., Sarmiento L. 1991. Adaptive Radiation of Espeletia in Cold Andean Tropics. Tree Trends Ecol. Evol. 6:387-391.

Pearson R. 2016. Association Analysis for Categorical Variables. Package ‘ GoodmanKruskal .' CRAN.:https://cran.r-project.org/web/packages/GoodmanKru.

Pope N.S., Jha S. 2018. Seasonal Food Scarcity Prompts Long-Distance Foraging by a Wild Social Bee. Am. Nat. 191:45-57.

Pouchon C., Fernández A., Nassar J.M., Boyer F., Aubert S., Lavergne S., Mavárez J. 2018. Phylogenomic analysis of the explosive adaptive radiation of the Espeletia complex (Asteraceae) in the tropical Andes. Syst. Biol. 67:1041-1060.

Pritchard J.K., Stephens M., Donnelly P. 2000. Inference of Population Structure Using Multilocus Genotype Data. Genet. Soc. Am. 155:945-959.

De Queiroz K. 1999. The general lineage concept of species and the defining properties of the species category. Species, New interdisciplinary essays. p. 49-89.

De Queiroz K. 2007. Species concepts and species delimitation. Syst. Biol. 56:879-886. 
Raftery A.E., Dean N. 2006. Variable selection for model-based clustering. J. Am. Stat. Assoc. 101:168-178.

Raj A., Stephens M., Pritchard J.K. 2014. FastSTRUCTURE: Variational inference of population structure in large SNP data sets. Genetics. 197:573-589.

Ramsay P.M., Oxley E.R. 1997. The growth form composition of plant communities in the Ecuadorian páramos. Plant Ecol. 131:173-192.

Rauscher J.T. 2002. Molecular Phylogenetics of the Espeletia Complex ( Asteraceae ): Evidence from nrDNA ITS Sequences on the Closest Relatives of an Andean Adaptive Radiation. Am. J. Bot. 89:1074-1084.

Raven P.H. 1986. Modern aspects of the biological species in plants. Modern aspects of species. eds Kunio Iwatsuki, Peter H. Raven, and Walter J. Bock. University of Tokyo Press: p. 1986.

Richards R.A. 2010. The Species Problem A philosophical Analysis. Published in the United States of America by Cambridge University Press, New York: .

Rieseberg L.H., Burke J.M. 2001. A genic view of species integration. 14:883-886.

Rieseberg L.H., Wood T.E., Baack E.J. 2006. The nature of plant species. Nature. 440:524-527.

Schindelin C.A., Rasband W.S., Eliceiri K.W. 2012. NIH Image to ImageJ: 25 years of image analysis. Nat. Methods. 9:671.

Schwartz G. 1978. Estimating the Dimension of a Model. Ann. Stat. 6:461-464.

Scrucca L., Raftery A.E. 2018. clustvarsel: A Package Implementing Variable Selection for Model-based Clustering in R. J. Stat. Software, Artic. 84.

Scrucca, L., Fop, M., Murphy, T. B., Raftery, A. E. (2016). mclust 5: clustering, classification and density estimation using Gaussian finite mixture models. The $\mathrm{R}$ journal, 8(1), 289.

Sigwart J.D. 2018. What Species Mean A User's Guide to the Units of Biodiversity. Kipling Will (University of California, Berkeley), CRC Press Taylor \& Francis 
Group: Charles R. Crumly, CRC Press/Taylor and Francis.

Spriggs E.L., Eaton D.A.R., Sweeney P.W., Schlutius C., Edwards E.J., Donoghue M.J. 2019. Restriction-Site-Associated DNA Sequencing Reveals a Cryptic Viburnum Species on the North American Coastal Plain. Syst. Biol. 68:187-203.

ter Steege H., Haripersaud P.P., Bánki O.S., Schieving F. 2011. A model of botanical collectors' behavior in the field: never the same species twice. Am. J. Bot. 98:31-7.

Struck T.H., Feder J.L., Bendiksby M., Birkeland S., Cerca J., Gusarov V.I., Kistenich S., Larsson K.H., Liow L.H., Nowak M.D., Stedje B., Bachmann L., Dimitrov D. 2018. Finding Evolutionary Processes Hidden in Cryptic Species. Trends Ecol. Evol. 33:153-163.

Sutton B.C.S., Flanagan D.J., Gawley J.R., Newton C.H., Lester D.T., El-Kassaby Y.A. 1991. Inheritance of chloroplast and mitochondrial DNA in Picea and composition of hybrids from introgression zones. Theor. Appl. Genet. 82:242-248.

Szllosi G.J., Tannier E., Daubin V., Boussau B. 2015. The inference of gene trees with species trees. Syst. Biol. 64:e42-e62.

Templeton A.R. 1989. The meaning of species and speciation: a genetic perspective. Speciation and its consequences. D. Otte and J. A. Endler, eds. Sinauer Associates, Sunderland, Massachusetts.: p. 3-27.

Templeton A.R. 2006. Population Genetics and Microevolutionary Theory. A John Wiley $\&$ Sons., Inc., Publication: .

Van Valen L. 1976. Ecological species, multispeciend oaks. Taxon. 25:233-239.

Verity R., Nichols R.A. 2016. Estimating the number of subpopulations (K) in structured populations. Genetics. 203:1827-1835.

Wu C.-I. 2001. The genic view of the process of speciation. Evol.Biol. 14:851-865. 


\section{TABLES}

Table 1: The thirteen morphological characters that we use to measure the phenotypic distinction between Espeletia species of páramo de Sumapaz

\begin{tabular}{ll}
\hline \multicolumn{3}{c}{ Morphological character } \\
\hline 1 & leaf blade length \\
3 & leaf blade width \\
4 & capitulum diameter \\
5 & number of pairs of sterile leaves per synflorescence \\
6 & length of the synflorescence axis \\
7 & perimeter of the synflorescence axis \\
8 & length of the cyma peduncle \\
9 & sterile phyllary length \\
10 & sterile phyllary width \\
11 & length of the corolla of the flowers in the disc \\
12 & length of the corolla of the flowers in the ray \\
\hline
\end{tabular}




\section{FIGURES}

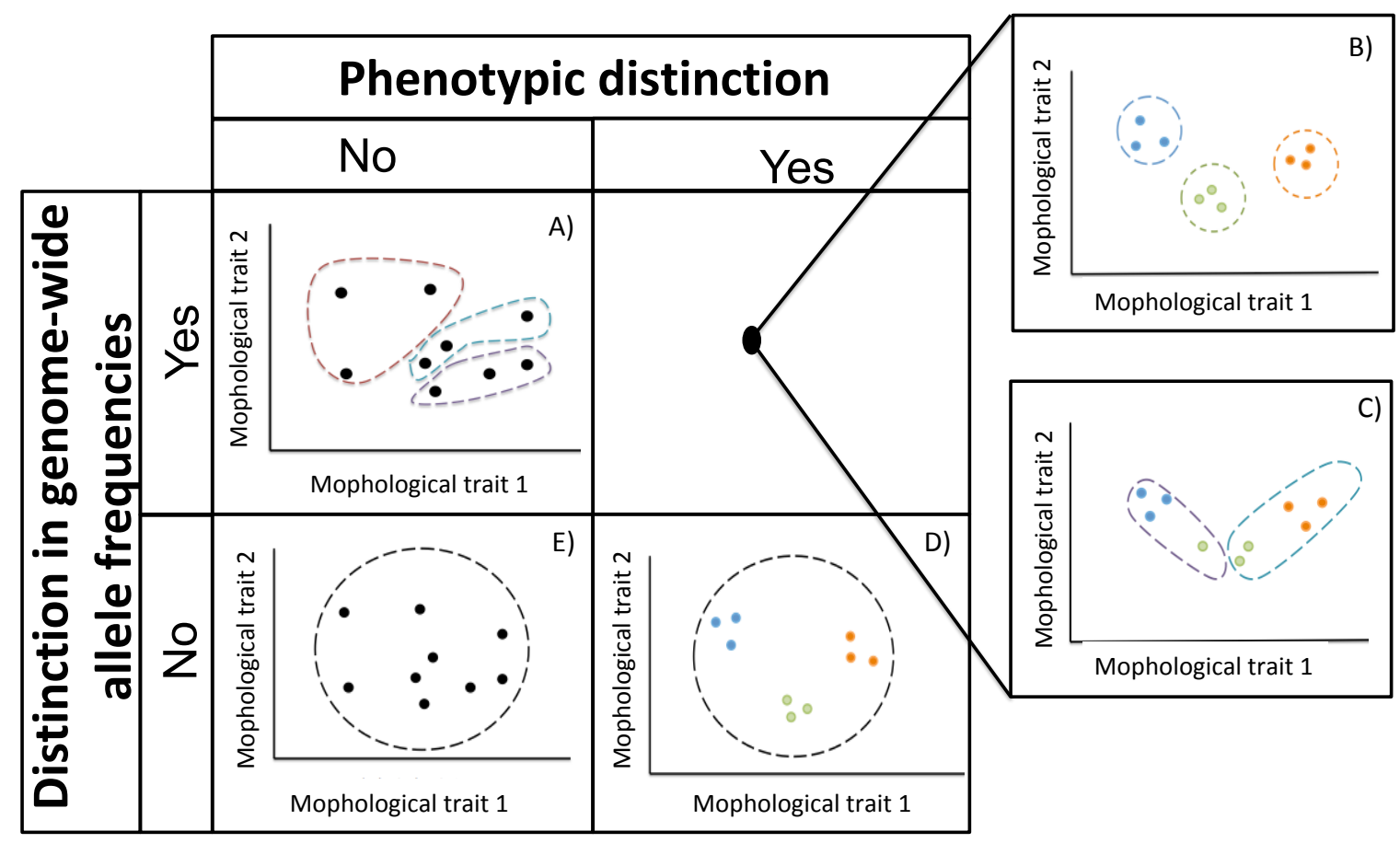

Figure 1. Possible scenarios of the nature of species in which the study specimens can be found under two operational criteria: phenotypic distinction and frequency of alleles. The points are individuals located in the space given by two morphological features, the colors are morphological groups and the lines represent the structure of the population. A) There are three groups with molecular structure, however there is no phenotypic distinction. B) Three morphological groups that belong to the genetic structure. C) There are three distinguishable morphological groups and there is a genetic structure, but the structure does not correspond to the morphological groups. D) There are three distinguishable phenotypic groups, but there is no genetic structure. E) It is a scenario where there is no genetic structure neither phenotypic distinction. 


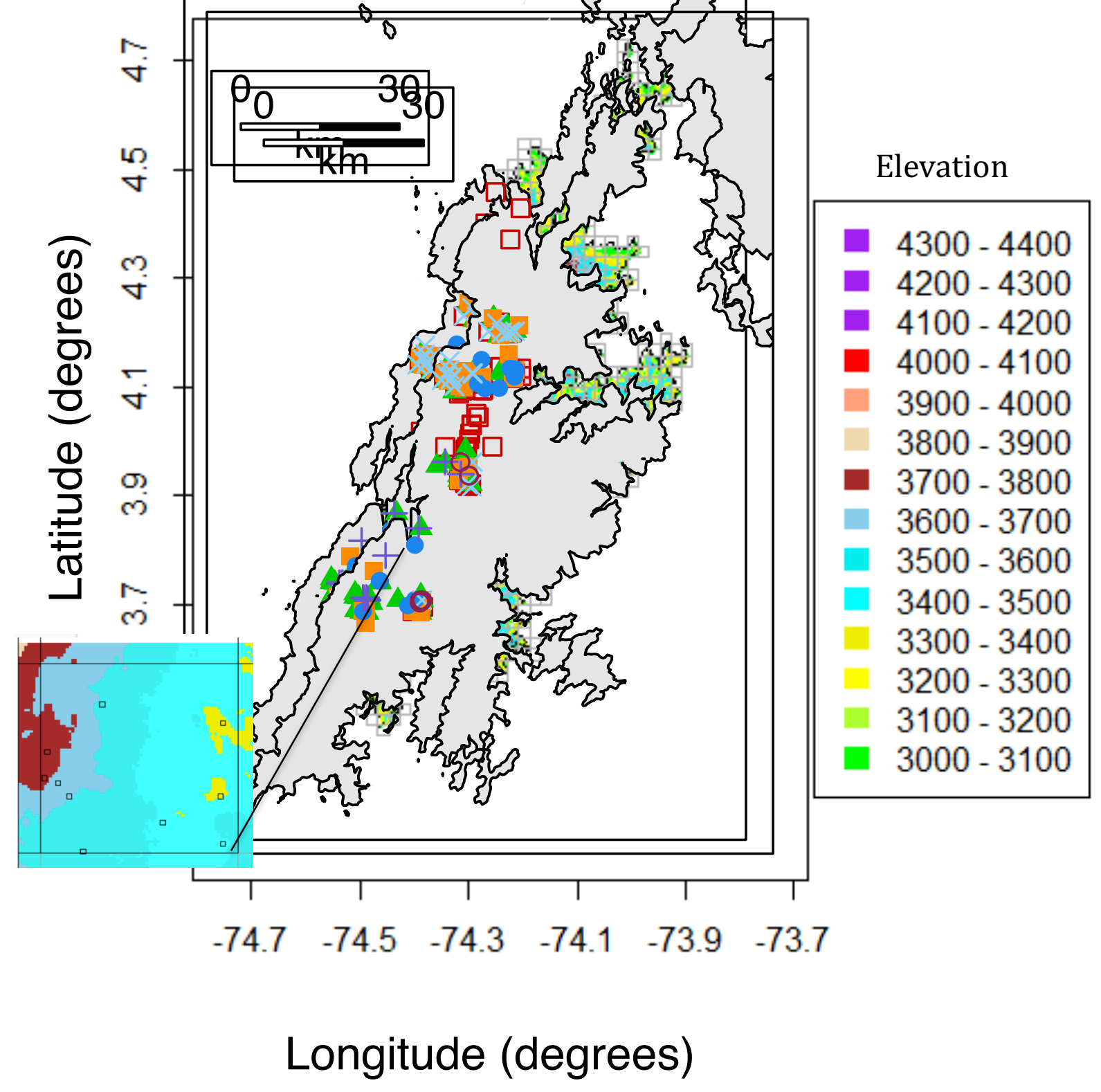

Figure 2. Topographic map of the study region, bounded by the altitude of $3,000 \mathrm{~m}$, based on the digital Aster elevation model. The study region was divided into quadrants of $2 \times 2 \mathrm{~km}$ (gray grid), of which we sampled 34 (black squares). In each of these 34 quadrants, we sampled two $30 \times 30 \mathrm{~m}$ cells in each band of $100 \mathrm{~m}$ altitude, chosen randomly based on the Aster digital elevation. For example, the $2 \times 2 \mathrm{~km}$ quadrant shown to the left of the figure has five elevation bands (as indicated by the color scale). Therefore, we sampled 10 cells of $30 \times 30 \mathrm{~m}$, two in each elevation band of $100 \mathrm{~m}$, as indicated by the black squares within the $2 \times 2 \mathrm{~km}$ quadrant. 

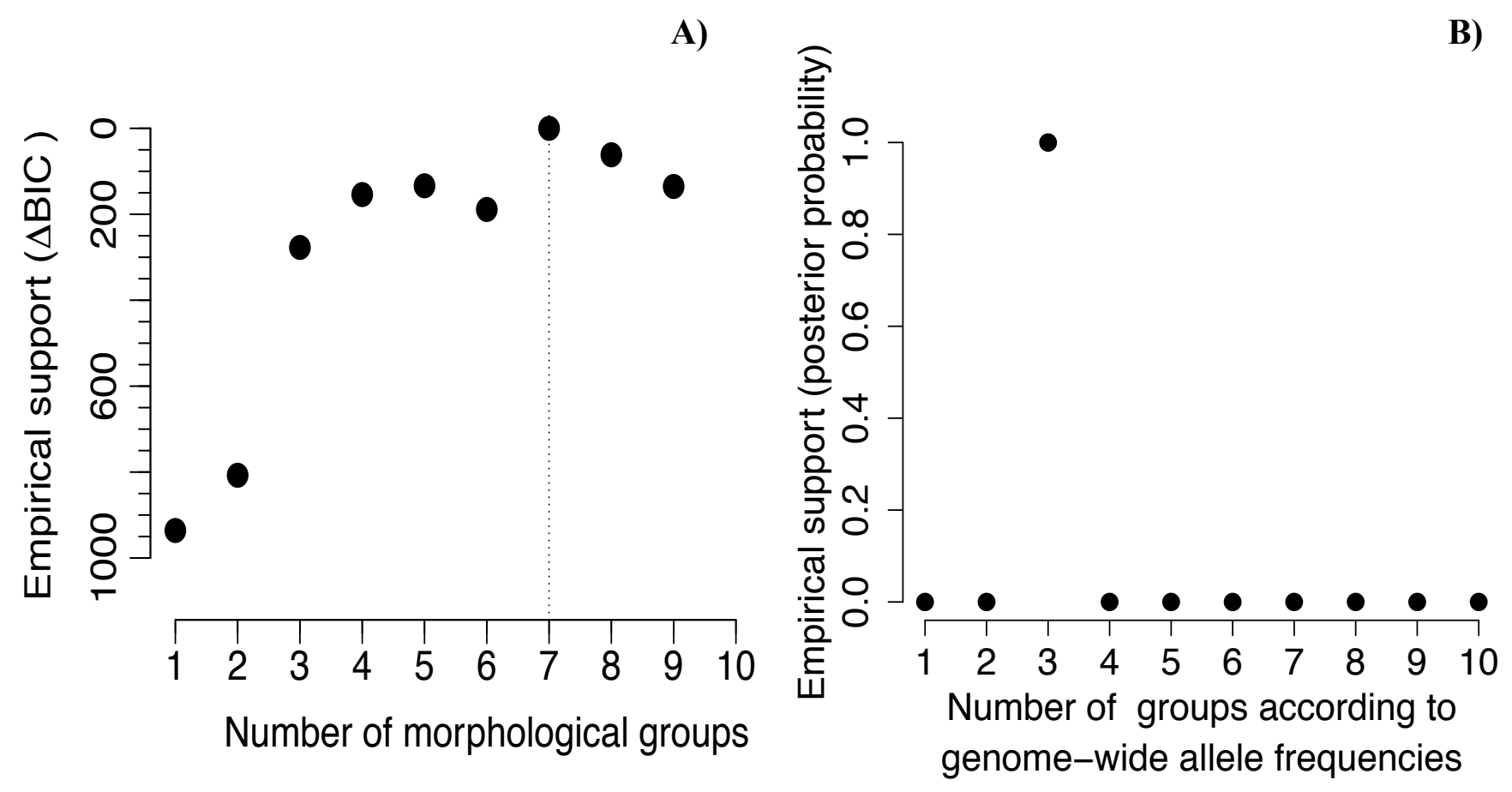

Figure 3. Empirical support to determine the number of groups: morphological and groups according to genome-wide allele frequencies. A) Analysis of strongly supported morphological data. The graph shows the empirical (ordered) support for the normal mixture models (NMM), assuming 1 to 10 different morphological groups. The empirical support was measured as the difference in BIC in relation to the best model $(\triangle B I C)$. The two models with the most empirical support assumed seven and eight different morphological groups. B) Analysis of data according to the allelic frequencies (Maverick). The graph shows the empirical support for the different K, assuming 1 to 10 groups according to genome-wide allele frequencies. The empirical support was measured by the posterior probability that numbers close to one have a higher empirical support. The model with the most empirical support assumed three groups according to allele frequencies. 


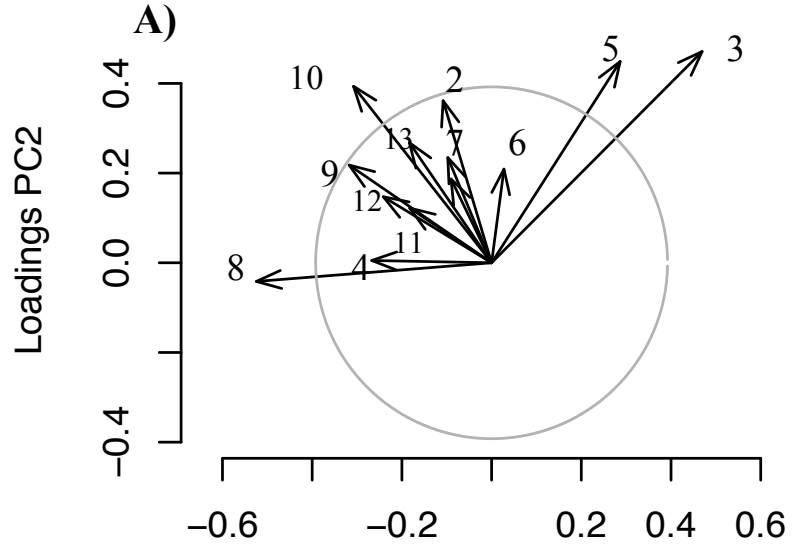

\section{Loadings PC1}

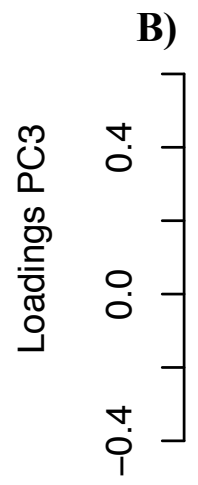

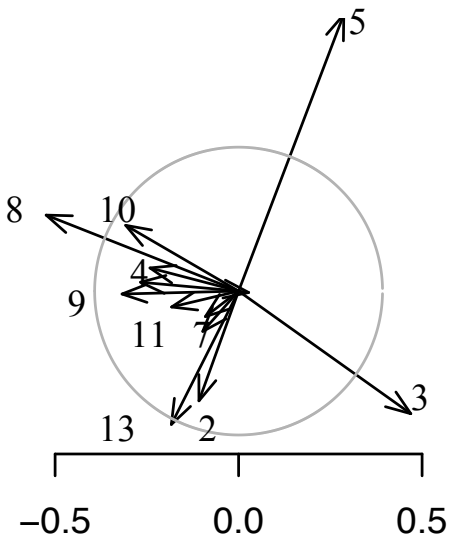

Loadings PC1
1. Leaf blade length

2. Leaf blade width

3. Number of capitula per synflorescence

4. Capitulum diameter

5. Number sterile leaves per synflorescence

6 . Length of the synflorescence axis

7. Perimeter of the synflorescence axis

8. Length of the cyma peduncle

9. Sterile phyllary length

10. Sterile phyllary width

11. Length of the corolla of the flowers in the disc

12. Length of the corolla of the flowers in the ray

13. Length of the tubes of the flowers in the disc

\section{C)}

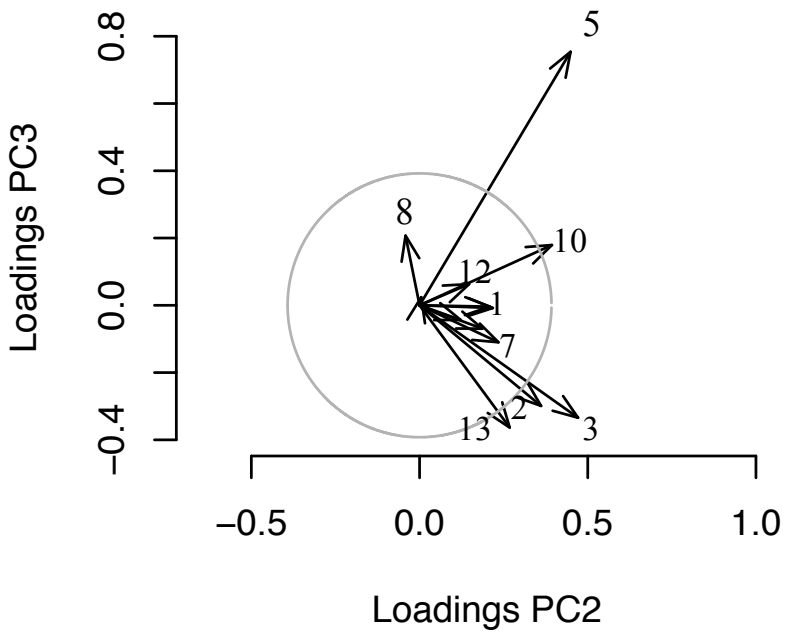

Figure 4. The contribution of the morphological features measured to the first three main components, measured by the loads of each feature in each main component (ie, elements of normalized eigenvectors). The circles show the length of the expected arrows if the thirteen features contributed equally to the spaces of two-dimensional main components; arrows that exceed this expectation contribute more significantly. A) Principal components analysis $1(41.9 \%)$ and $2(17.4 \%)$, these explain $59.3 \%$ of the total variation, $\mathrm{PC} 1$ and $\mathrm{PC} 2$ reflect general aspects of the number of capitula per synflorescence, number of pairs of sterile leaves per synflorescence, sterile phyllary width and length of the cyma peduncle. B) Principal components analysis 1 (41.9\%) and $3(11 \%)$, these explain $52.9 \%$ of the total variation. PC1 and PC3 reflect general aspects of capitulum diameter, number of pairs of sterile leaves per synflorescence and length of the cyma peduncle. C) Principal components analysis $2(17.4 \%)$ and $3(11 \%)$, these explain $28.4 \%$ of the total variation. PC2 and PC3 reflect general aspects $2,4,5,10,13$ (Table1). 
A)

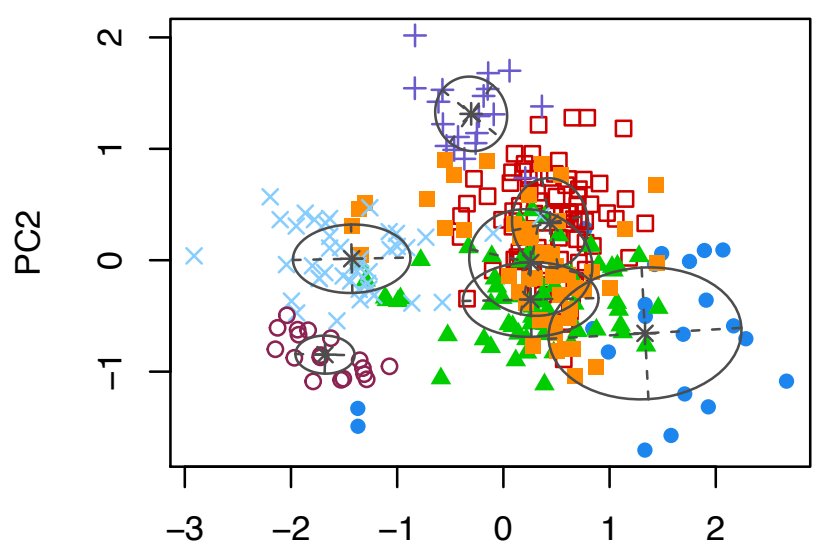

Morphological Group 1

Morphological Group 2

- Morphological Group 3

+ Morphological Group 4

Morphological Group 5

Morphological Group 6

Morphological Group 7
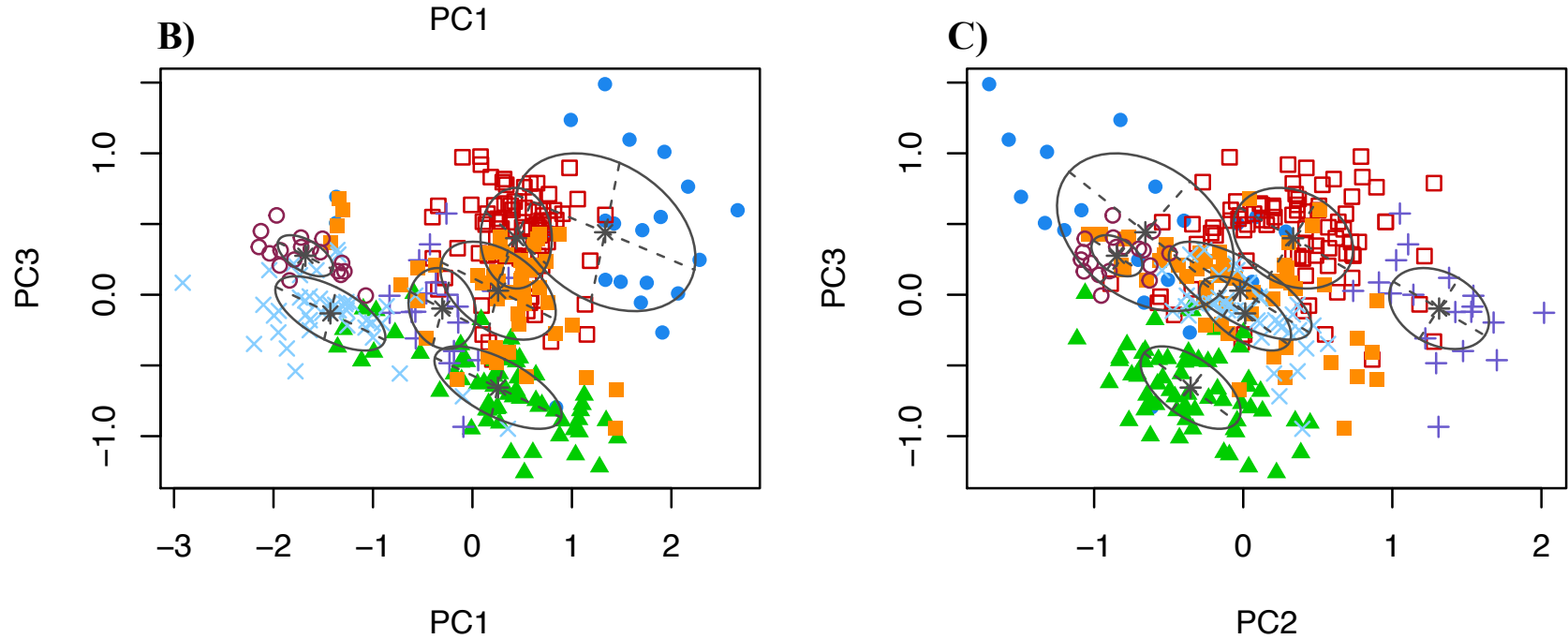

Figure 5. Seven morphological groups of Espeletia identified using normal mixture model (NMM) based on all the characters, but the components $(1,2,3,5,6,7,8,9,10)$ that showed the clust-vasel as useful (A - C). It shows the groups in the space defined by the three most useful main components for group discrimination (PC1 - PC3). The colored symbols represent specimens assigned to different morphological groups and the ellipses show $95 \%$ of high density regions for normal distributions that represent each morphological group. 


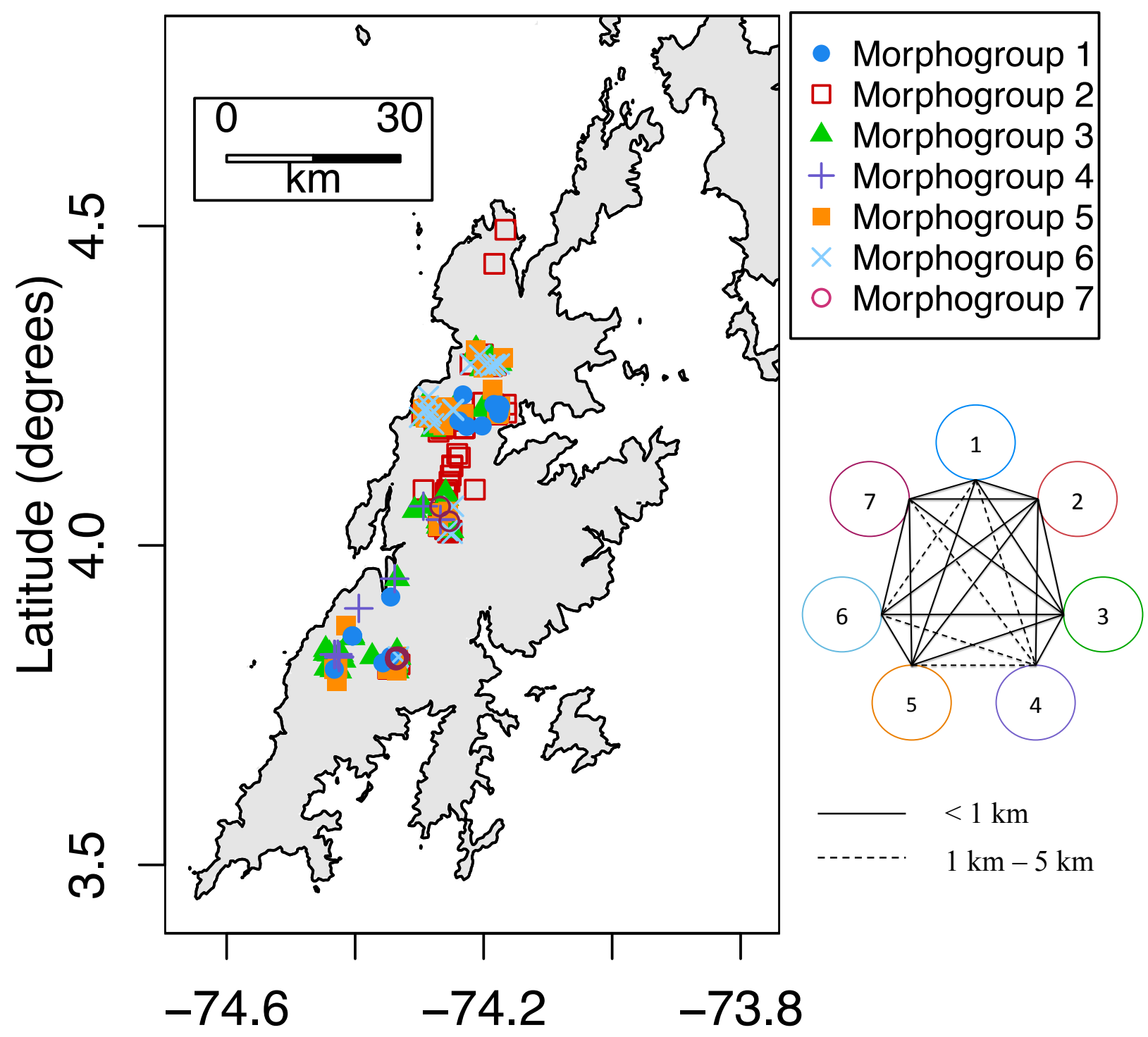

\section{Longitude (degrees)}

Figure 6. Map of occurrences of the specimens, the colors and symbols correspond to the seven groups that the NMM revealed. The continuous line of the relationship graph means that the two groups that connect the line with the nearest neighbor are less than one kilometer away. The dotted line means that the two groups are at a distance with the nearest neighbor greater than one kilometer but less than five kilometers. 

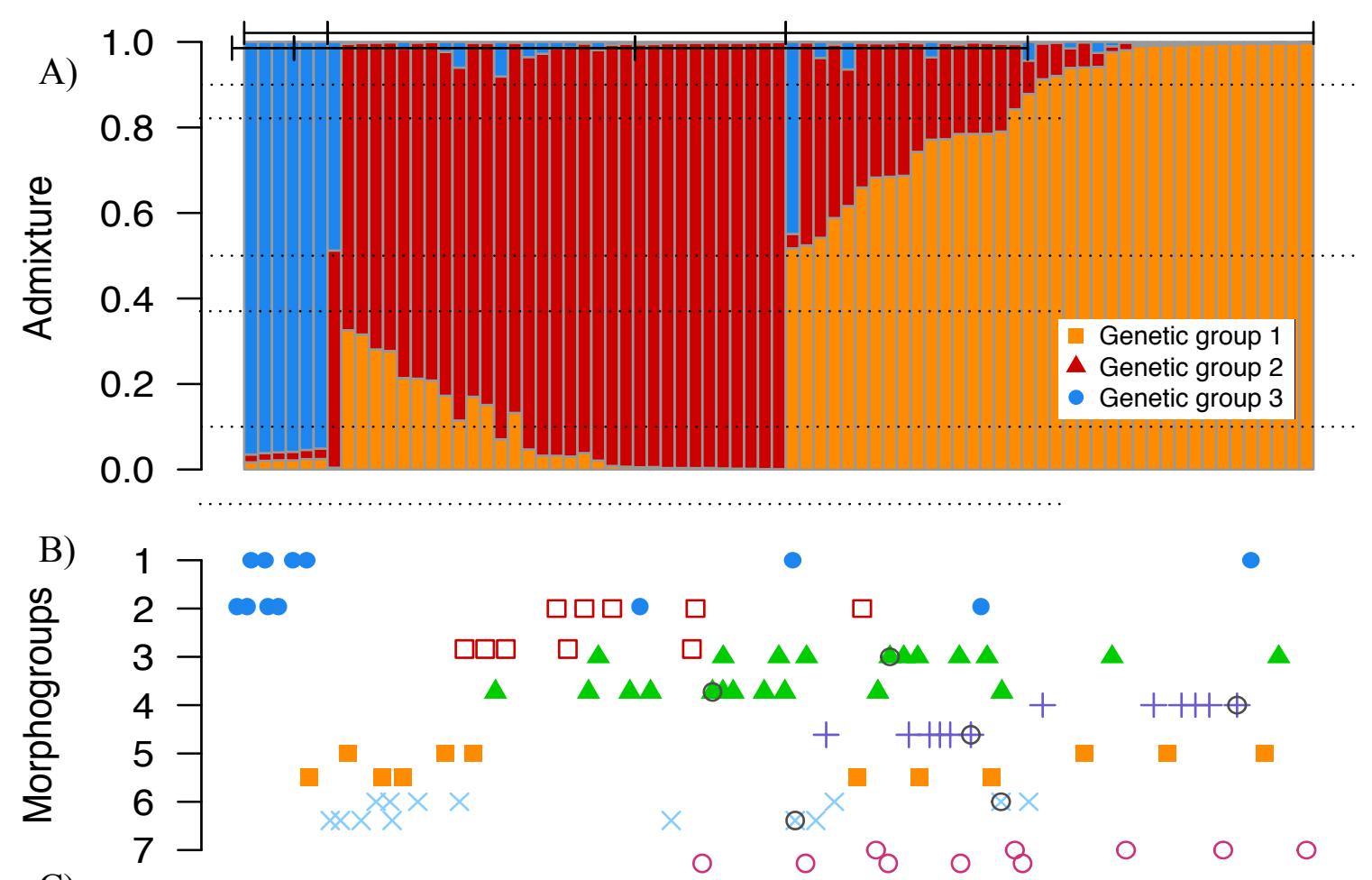

C)

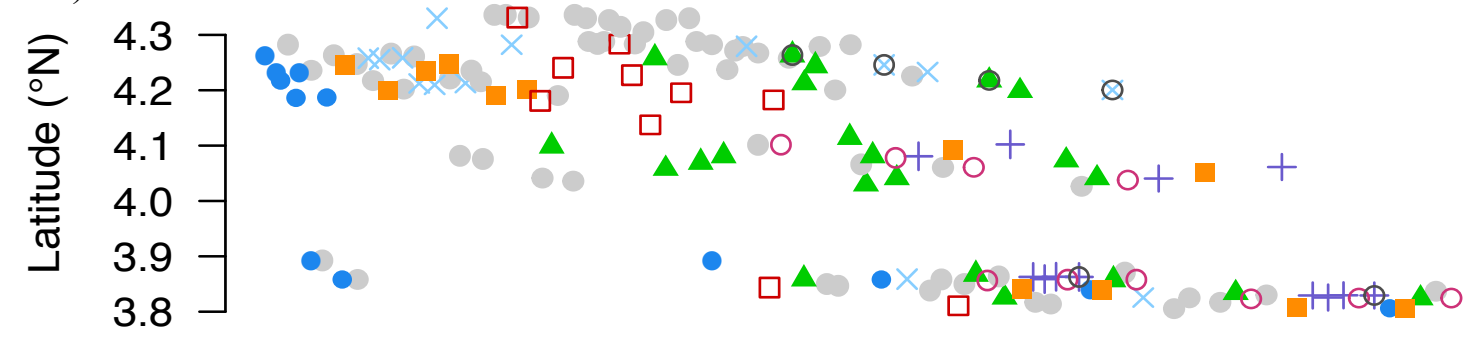

Figure 7. Comparative analysis between allele frequencies, morphological groups and their latitude position. A) There are 77 samples organized by their admixture percentage. The colors refer to the three groups with more empirical support according to the allele frequencies. In the upper part with a continuous line, each of the three groups is delimited and with a dotted line three levels of admixture are drawn: (0.1.0.5 and 0.9). From right to left is group 1 according to the allele frequencies and it is observed how the admixture increases to the left with group 2 (red) and finally group 3 in blue. B) The colored symbols represented specimens assigned to the seven morphological groups of the NMM, and are organized on the $\mathrm{x}$ axis by the position of the samples of the analysis of allele frequencies, to compare between the morphogroup and the genetic group to which each specimen belongs. C) The colored symbols represented specimens assigned to the seven morphological groups of the NMM and the gray points are specimens that are part of the analysis of alelic frequencies but were not assigned to a morphogroup. In the axis and Latitude (degrees north), that is to say that having a high number, the geographical position is more to the north (small numbers, more to the south). In the $\mathrm{x}$-axis are organized by the position of the samples of the analysis of alelic frequencies which allows us to observe the position of the groups alelic geographically. 


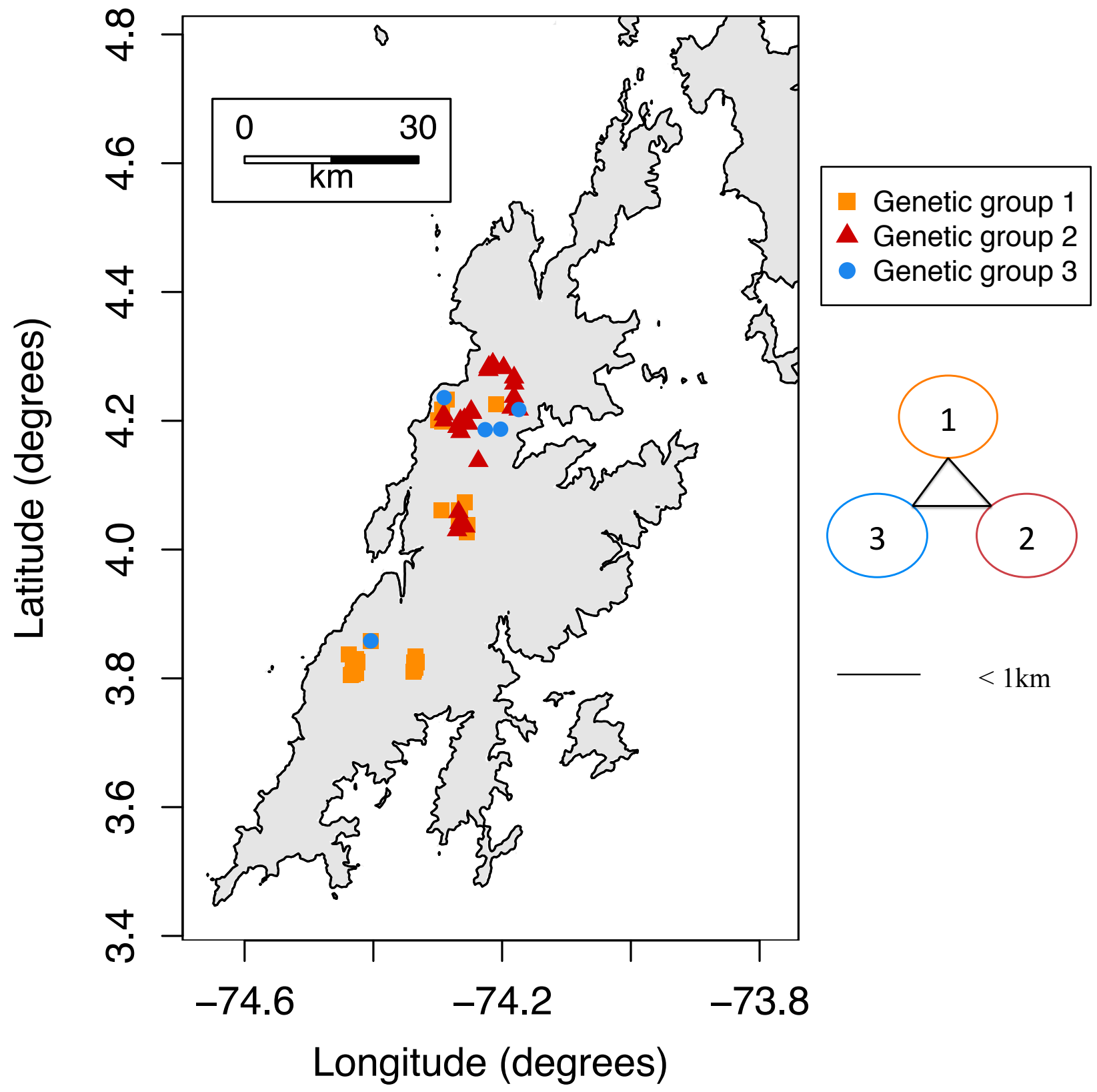

Figure 8. Map of occurrences of the specimens, classified according to allele frequencies groups. The continuous line of the relationship graph means that the two groups that connect the line with the nearest neighbor are less than one kilometer away. 


\section{SUPPLEMENTARY MATERIAL}

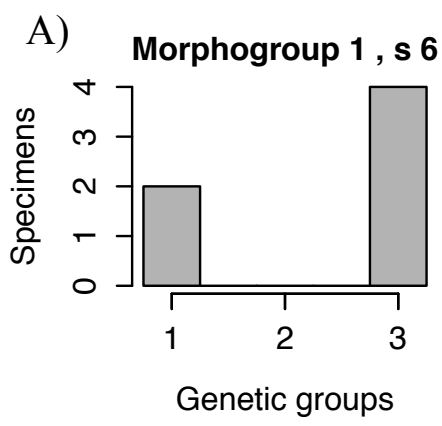

D) Morphogroup $4, \mathrm{~s} 6$

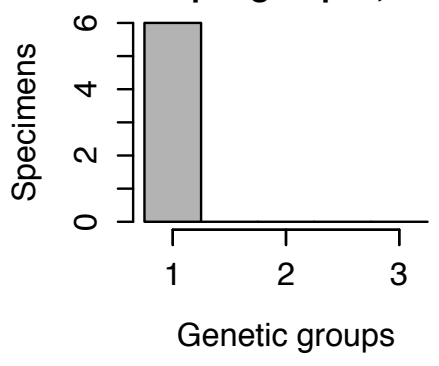

G) Morphogroup 7, s 5

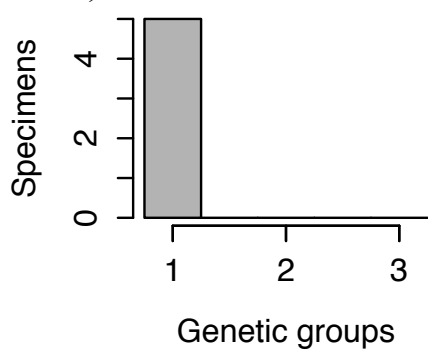

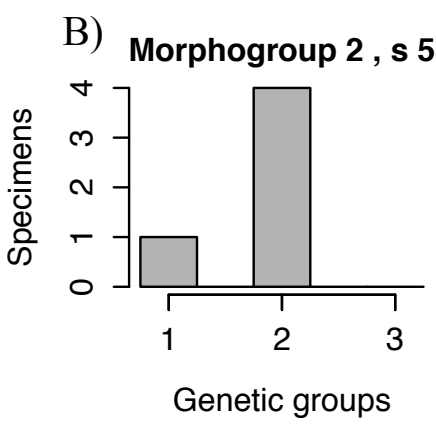
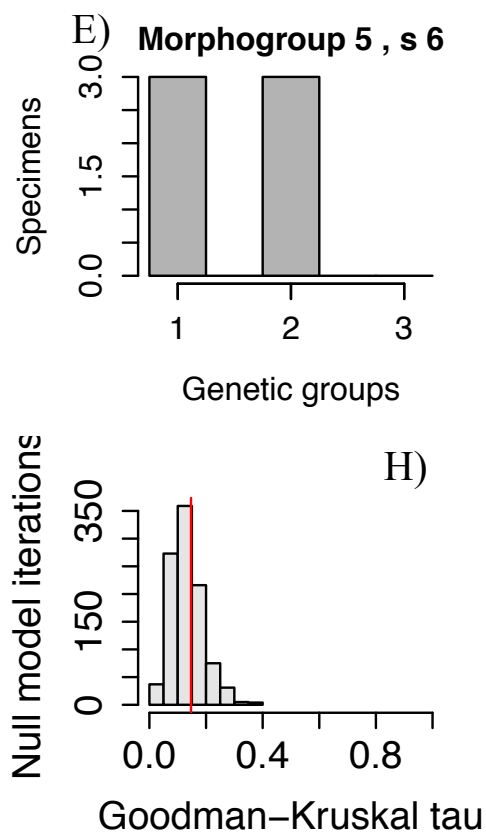
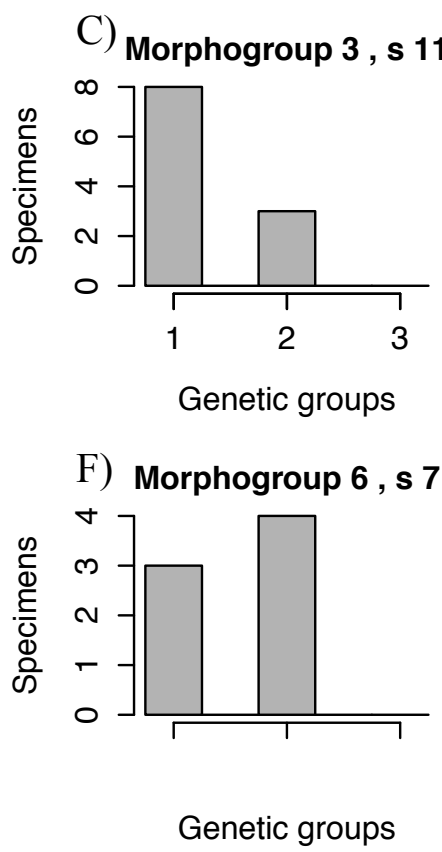

Supplementary Figure 1. Comparison of the groups according to allele frequencies and the morphogroups provided with the NMM. A) In the first morphogroup there are 6 specimens which are found: two in the genetic group land three in the genetic group 3. B) In the second morphogroup there are 5 specimens; one in the genetic group 1 and four in genetic group 2. C) In the third morphogroup there are 11 specimens; eight in the genetic group 1 and three in genetic group 2. D) The fourth morphogroup the 6 specimens belong to the genetic group 1. E) In the fifth morphogroup there are 6 specimens; three in the genetic group 1 and three in genetic group 2. F) In the sixth morphogroup there are 7 specimens; three in the genetic group 1 and four in genetic group 2. G) The seventh morphogroup the 5 specimens belong to the genetic group $1 . \mathrm{H}$ ) The null hypothesis of no association between the two classifications, represented by the Goodman-Kruskal tau distribution, produced by a null model of randomization of the data. Significance of how the group given by the allelic frequencies predicts the morphological group. The red line is the value tau yx 0.147 of the test ( $p$-value $>0.001$ ). 
A)

Genetic group 1 , specimens 28

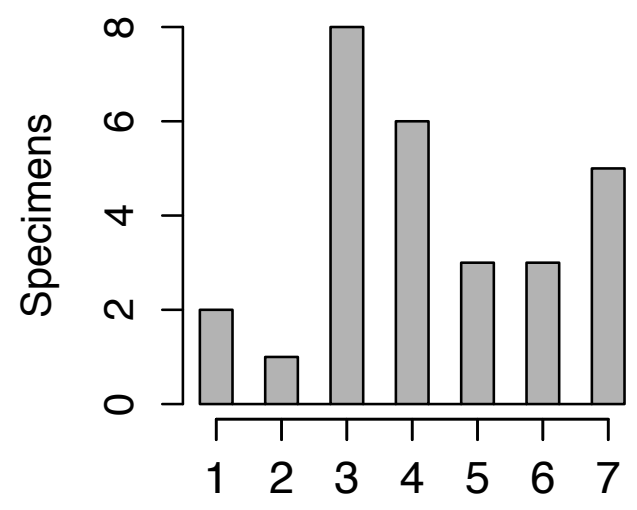

Morphogroups

C)

Genetic group 3 , specimens 4

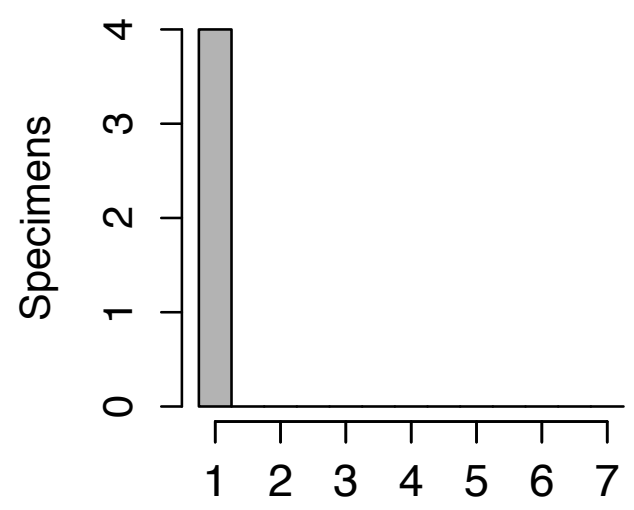

Morphogroups
B)

Genetic group 2 , specimens 14

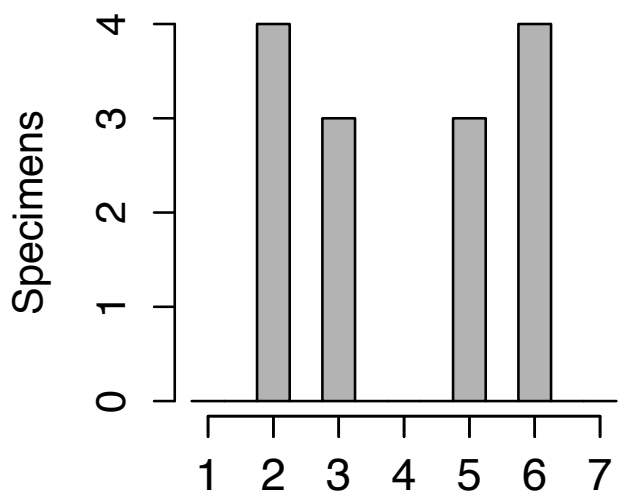

D)
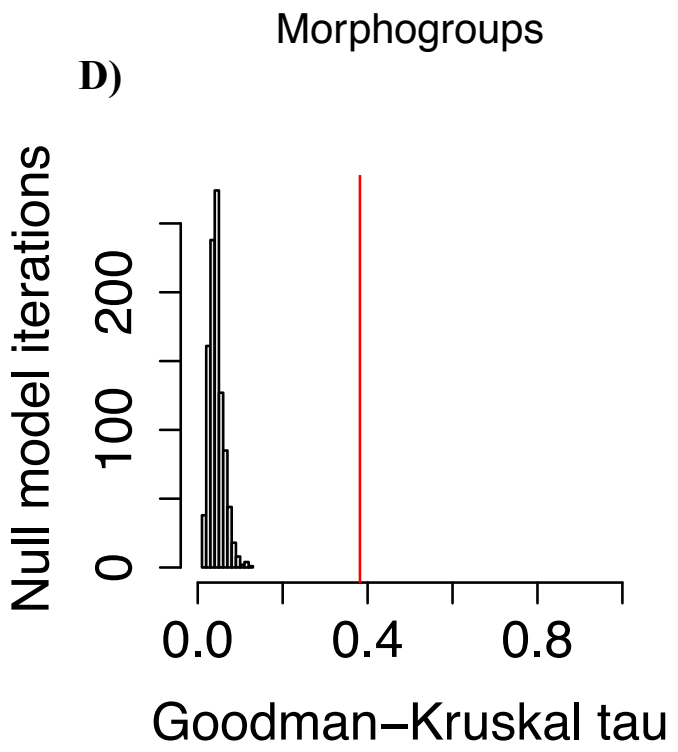

Supplementary Figure 2. Comparison of the classifications provided with the NMM and the groups according to allele frequencies. A) In the first genetic group there are 28 specimens which are found: two in the morphogroup 1, one in the morphogroup 2, eight in morphogroup 3, six in the morphogroup 4, three in the morphogroups 5 and 6 , and five the morphogroup 7. B) In the second genetic group there are 14 specimens; four in the morphogroup 2, three in morphogroup 3, three in group 5 and four in group 6. C) The third genetic group the four species belong to the morphological group 1. D) The null hypothesis of no association between the two classifications, represented by the Goodman-Kruskal tau distribution, produced by a null model of randomization of the data. Significance of how the group given by the allelic frequencies predicts the morphological group. The red line is the value tau xy 0.382 of the test ( $p$-value $<0.001$ ). 

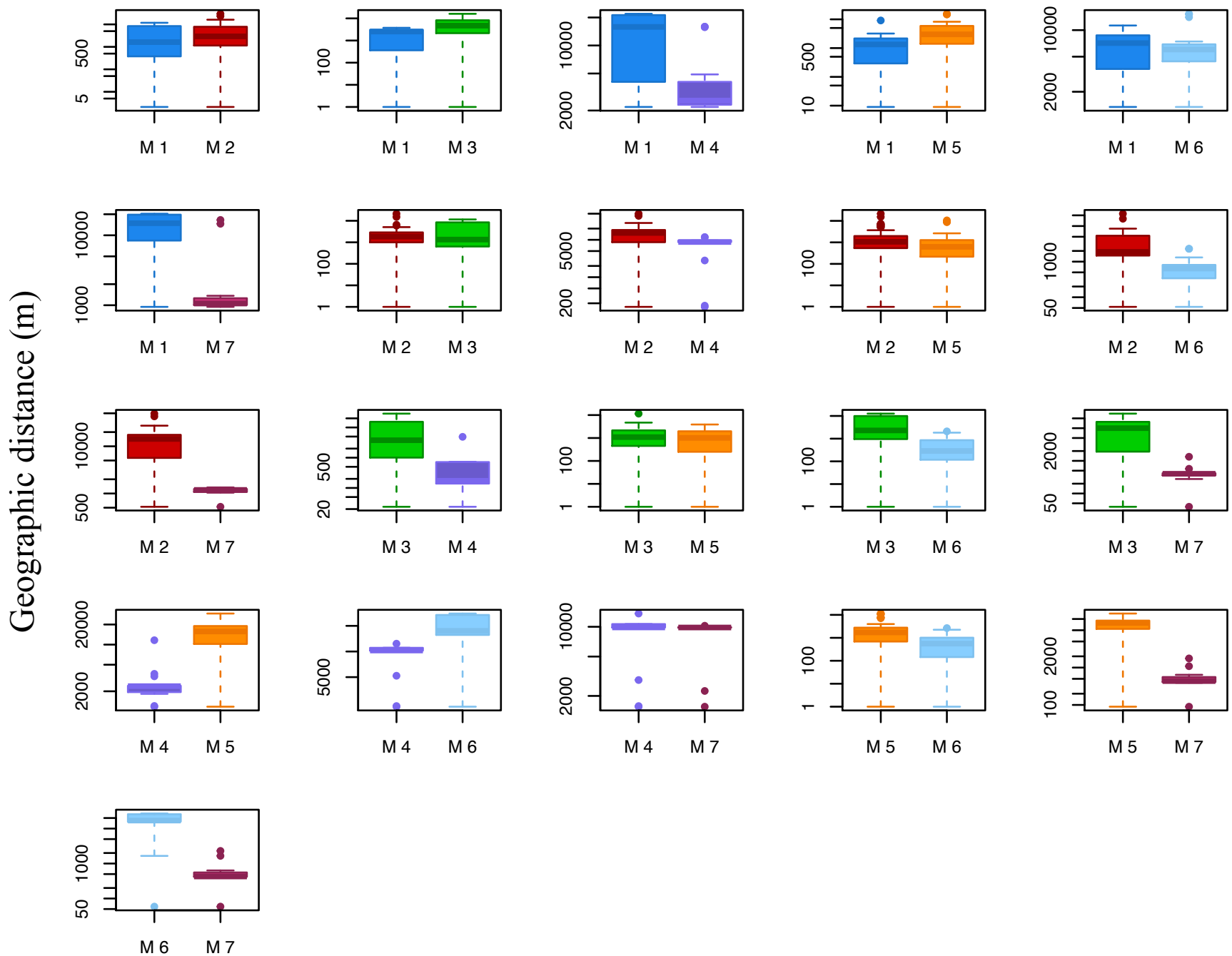

Supplementary Figure 3 Box-plots of the geographical distance to the nearest neighbor between pairs of groups of the seven moroghoups revealed by the NMM. 


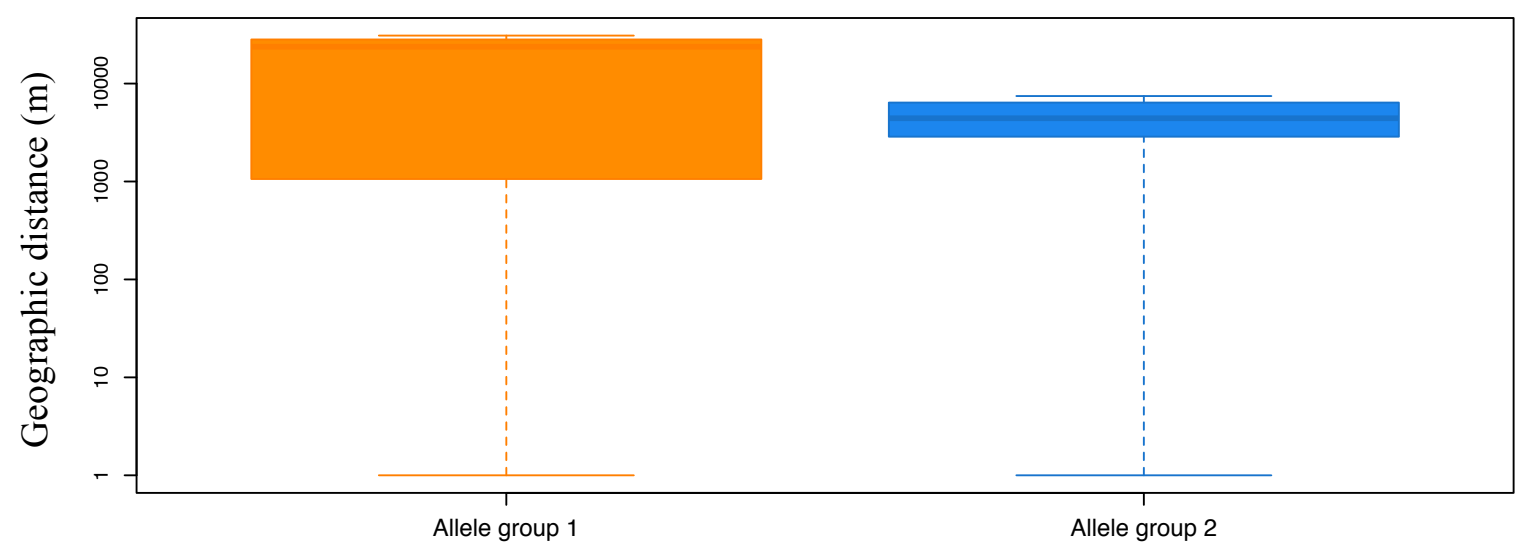

(38 specimens)

(33 specimens)
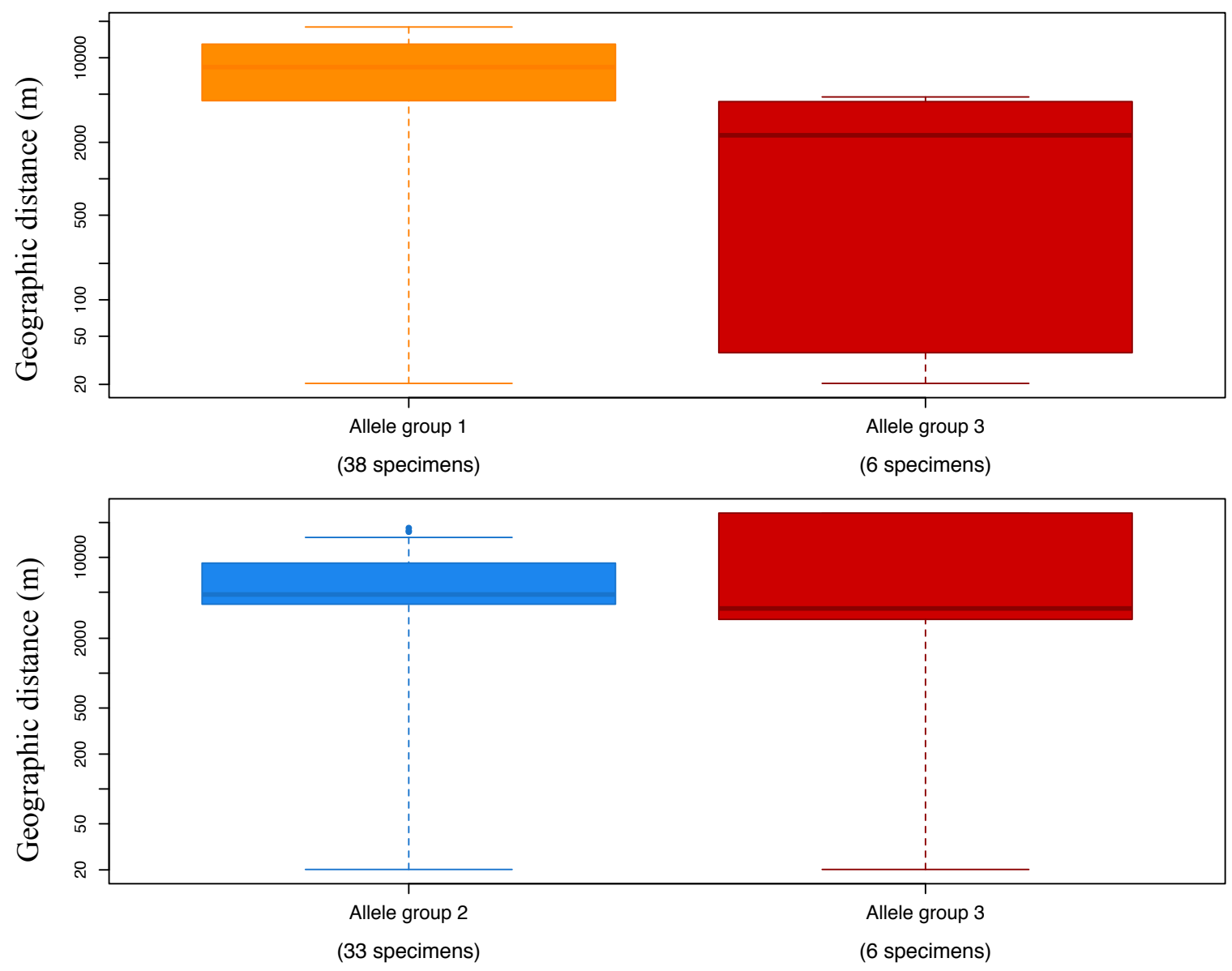

Supplementary Figure 4. Box-plots of the geographical distance to the nearest neighbor between pairs of groups of the three groups according to allele frequencies. 


\section{Supplementary table of morphological data}

Colector

Pineda Yam

Pineda Yam

Pineda Yam

Pineda Yam

Pineda Yam

Pineda Yam

Pineda Yam

Pineda Yam

Pineda Yam

Pineda Yam

Pineda Yam

Pineda Yam

Pineda Yam

Pineda Yam

Pineda Yam

Pineda Yam

Pineda Yam

Pineda Yam

Pineda Yam

Pineda Yam

Pineda Yam

Pineda Yam

Pineda Yam

Pineda Yam

Pineda Yam

Pineda Yam

Pineda Yam

Pineda Yam

Pineda Yam

Pineda Yam

Pineda Yam

Pineda Yam

Pineda Yam

Pineda Yam

Pineda Yam

Pineda Yam

Pineda Yam

Pineda Yam

Pineda Yam

Pineda Yam

Pineda Yam

Pineda Yam

Pineda Yam

Pineda Yam

Pineda Yam

Pineda Yam

Pineda Yam

Pineda Yam

Pineda Yam

Pineda Yam

Pineda Yam

Pineda Yam

Pineda Yam

Pineda Yam

Pineda Yam

Pineda Yam

Pineda Yam

Pineda Yam

Pineda Yam

Pineda Yam

Pineda Yam
C Number Longitud Latitud Length.LiWidth.LaLength.S Perimet €NumbNumb€Length.CDiamete Length.S Width.StRay.FlouDisc.FlovDisc.Flower.Tube

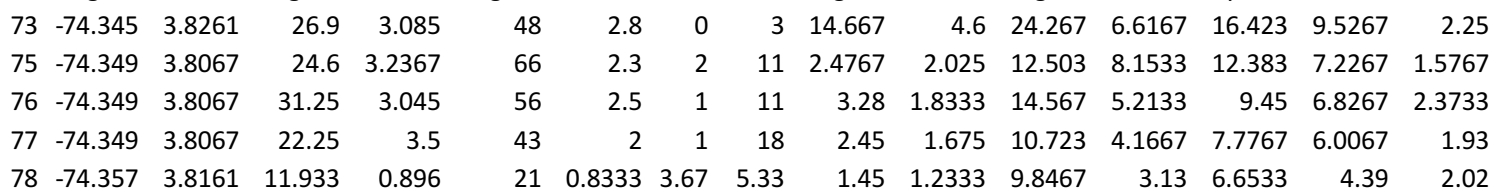

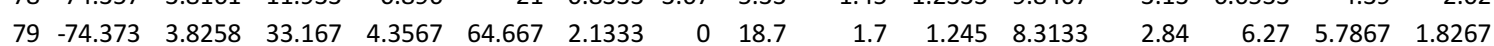
$\begin{array}{lllllllllllllllll}81 & -74.187 & 4.2443 & 31.7 & 3.05 & 71 & 2.2333 & 1 & 13 & 3.4883 & 1.58 & 13.917 & 4.4433 & 10.68 & 6.1967 & 1.9033\end{array}$ $\begin{array}{llllllllllllllllll}88 & -74.174 & 4.2174 & 43.46 & 3.6977 & 87 & 2.3667 & 1 & 14.3 & 4.3867 & 1.6975 & 10.71 & 4.9967 & 8.6433 & 5.9833 & 1.36\end{array}$ $\begin{array}{lllllllllllllllll}90 & -74.174 & 4.2174 & 21.307 & 1.1333 & 44.5 & 1.35 & 2 & 11.5 & 3.346 & 1.0625 & 5.32 & 3.35 & 3.4733 & 2.7467 & 1.16\end{array}$

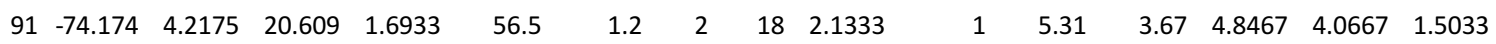
$\begin{array}{llllllllllllllll}99 & -74.175 & 4.2197 & 33.514 & 1.338 & 101.5 & 2.0667 & 3 & 10.3 & 5.8833 & 1.1 & 5.4167 & 3.4667 & 5.4367 & 3.57 & 1.1467\end{array}$ $\begin{array}{rllllllllllllllll}146 & -74.188 & 4.2413 & 34.864 & 3.243 & 87.333 & 1.9 & 1.5 & 13.3 & 1.1433 & 1.9975 & 14.757 & 5.23 & 13.727 & 5.8 & 1.4267\end{array}$ $\begin{array}{lllllllllllllllll}152 & -74.184 & 4.2206 & 29.918 & 3.873 & 70.667 & 1.6667 & 1.5 & 8.67 & 2.7667 & 1.6125 & 11.747 & 4.7233 & 7.2 & 5.8833 & 1.9733\end{array}$

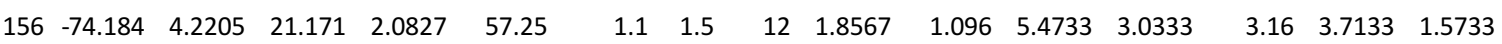
$\begin{array}{llllllllllllllll}157 & -74.184 & 4.2205 & 28.012 & 2.9363 & 73.333 & 2.5667 & 2 & 14 & 4.075 & 1.5125 & 5.8567 & 4.1567 & 9.5067 & 5.6933 & 1.8667\end{array}$ $\begin{array}{lllllllllllllllll}164 & -74.201 & 4.2232 & 33.677 & 3.2467 & 80.333 & 1.3667 & 3 & 5.67 & 3.3333 & 1.5875 & 16.033 & 5.6367 & 13.327 & 6.5267 & 2.26\end{array}$ $\begin{array}{llllllllllllllll}166 & -74.201 & 4.2231 & 38.321 & 4.3127 & 87.333 & 2.6333 & 2 & 11.7 & 3.1067 & 2.425 & 16.88 & 7.2233 & 12.867 & 7.06 & 2.61\end{array}$ $\begin{array}{llllllllllllllll}176 & -74.176 & 4.215 & 39.844 & 4.9937 & 57.667 & 2.2333 & 0.5 & 15.3 & 3.1967 & 2.1267 & 9.3 & 4.94 & 15.64 & 6.2967 & 2.1267\end{array}$ $\begin{array}{llllllllllllllll}178 & -74.176 & 4.215 & 40.323 & 5.4917 & 104.67 & 2.2667 & 2 & 18.7 & 4.055 & 1.764 & 10.353 & 4.4033 & 10.935 & 5.9867 & 1.5667\end{array}$ $\begin{array}{lllllllllllllllll}181 & -74.176 & 4.2123 & 37.328 & 2.7787 & 53.333 & 1.45 & 1 & 21.5 & 1.7067 & 1.3975 & 4.6333 & 3.5067 & 4.5967 & 3.5633 & 1.84\end{array}$

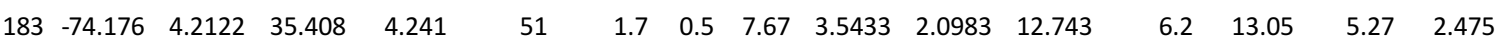

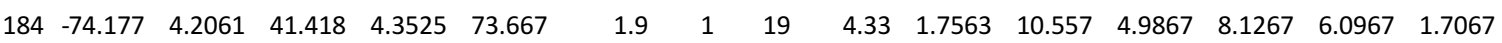

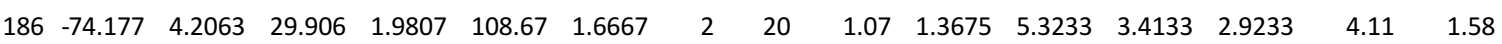
$\begin{array}{llllllllllllllll}190 & -74.18 & 4.2049 & 37.274 & 4.375 & 75.5 & 1.6333 & 1 & 9 & 3.1917 & 1.85 & 11.473 & 3.5333 & 9.82 & 5.8633 & 1.9633\end{array}$ $\begin{array}{llllllllllllllll}191 & -74.18 & 4.2049 & 24.595 & 2.5117 & 65 & 1.55 & 1 & 8 & 1.2738 & 1.3075 & 14.09 & 5.9133 & 11.14 & 5.7733 & 1.57\end{array}$

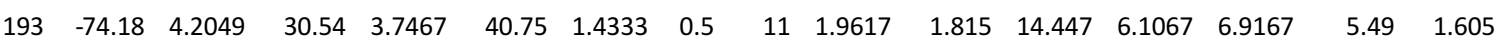
$\begin{array}{llllllllllllllll}195 & -74.18 & 4.2049 & 32.744 & 3.507 & 79.667 & 1.2333 & 3 & 8.67 & 1.345 & 1.6875 & 13.917 & 6.2033 & 14.467 & 7.0733 & 2.5167\end{array}$ $\begin{array}{llllllllllllllll}197 & -74.18 & 4.2049 & 36.178 & 4.068 & 85.567 & 2.0333 & 3 & 8 & 2.6933 & 1.775 & 14.973 & 8.7833 & 11.33 & 6.1667 & 1.6333\end{array}$

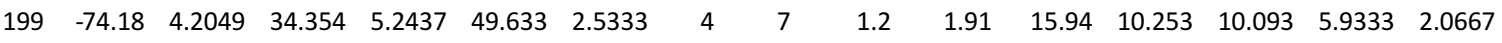

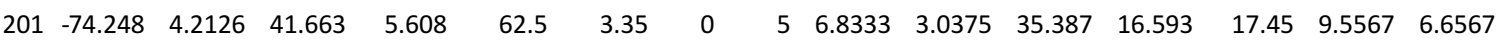
$\begin{array}{llllllllllllllll}204 & -74.253 & 4.2078 & 26.692 & 4.4333 & 61.667 & 2.4 & 0.5 & 11.3 & 2.3417 & 1.4275 & 10.347 & 6.74 & 9.4033 & 7.26 & 3.2633\end{array}$ $\begin{array}{llllllllllllllll}207 & -74.259 & 4.2022 & 32.942 & 5.4553 & 55.333 & 2.0333 & 1 & 5.33 & 7.6683 & 2.71 & 17.713 & 15.593 & 10.09 & 6.7767 & 4.5367\end{array}$ $\begin{array}{lllllllllllllllll}218 & -74.287 & 4.2177 & 35.078 & 3.7787 & 53 & 1.9667 & 1 & 17.7 & 2.31 & 1.1725 & 7.0833 & 3.5033 & 7.4433 & 6.0133 & 2.28\end{array}$

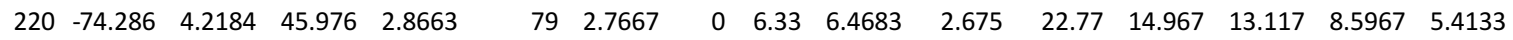

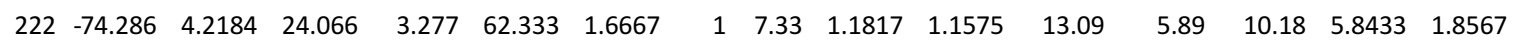

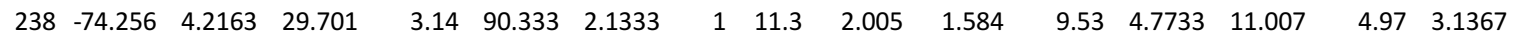

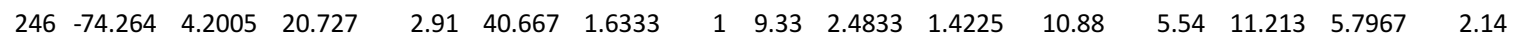

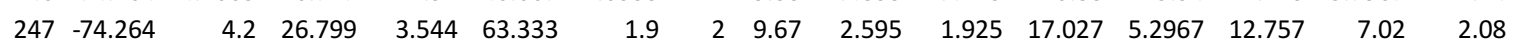

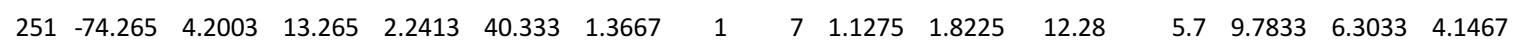
$\begin{array}{llllllllllllllll}253 & -74.272 & 4.1975 & 18.601 & 2.9123 & 49.333 & 1.4667 & 0.5 & 9.33 & 1.125 & 1.915 & 12.77 & 6.47 & 9.0433 & 5.6633 & 2.13\end{array}$

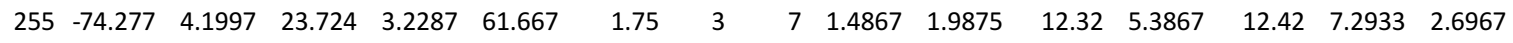
$\begin{array}{rllllllllllllllll}259 & -74.284 & 4.2025 & 40.861 & 3.9957 & 79.333 & 2.2333 & 0 & 5 & 3.4083 & 2.8775 & 24.683 & 20.27 & 16.717 & 9.4433 & 5.65\end{array}$

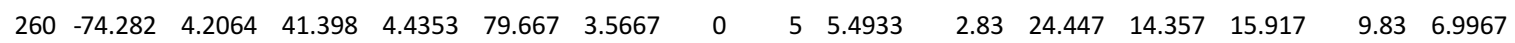

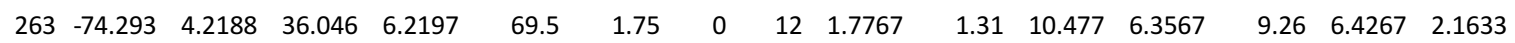
$\begin{array}{llllllllllllllll}287 & -74.264 & 4.1956 & 26.981 & 3.6703 & 86.667 & 1.7667 & 2 & 16.3 & 2.0617 & 1.8375 & 12.003 & 6.9767 & 8.44 & 6.0733 & 1.4833\end{array}$

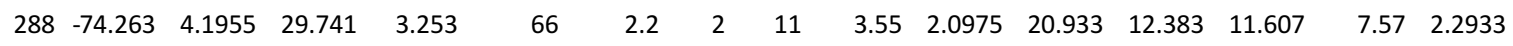
$\begin{array}{llllllllllllllll}290 & -74.266 & 4.2158 & 39.242 & 5.2333 & 91.333 & 2.0667 & 1 & 21.7 & 1.4633 & 1.8175 & 12.623 & 6.52 & 13.433 & 5.9533 & 4.47\end{array}$

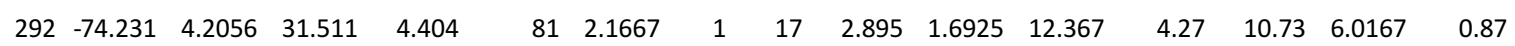
$\begin{array}{llllllllllllllll}294 & -74.235 & 4.2043 & 24.74 & 2.971 & 54.667 & 1.8 & 2 & 7 & 1.68 & 1.9125 & 14.397 & 7.3567 & 12.61 & 5.7533 & 1.3767\end{array}$ $\begin{array}{rlllllllllllllll}295 & -74.235 & 4.2023 & 25.081 & 4.7797 & 73.333 & 2.0333 & 1.5 & 12.3 & 2.1567 & 2.175 & 15.093 & 6.31 & 12.86 & 6.6033 & 4.27\end{array}$

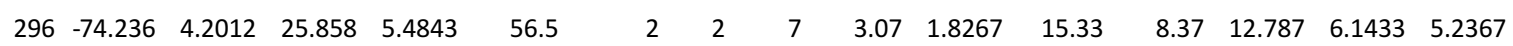

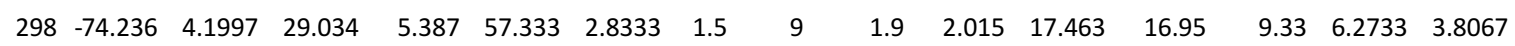
$\begin{array}{lllllllllllllllll}303 & -74.238 & 4.1977 & 35.749 & 5.011 & 58.667 & 2.8333 & 1 & 5.67 & 11.03 & 2.405 & 15.94 & 11.46 & 11.283 & 7.7967 & 1.85\end{array}$ $\begin{array}{rlllllllllllllll}304 & -74.251 & 4.1947 & 34.716 & 3.666 & 84.333 & 2.7333 & 2 & 16 & 3.3 & 2.1125 & 14.107 & 8.02 & 8.03 & 5.85 & 1.57\end{array}$ $\begin{array}{llllllllllllllll}306 & -74.263 & 4.1839 & 30.201 & 3.4783 & 110.33 & 2.0333 & 3.5 & 12 & 2.4633 & 1.61 & 16.393 & 5.5333 & 9.2367 & 5.7867 & 1.6267\end{array}$

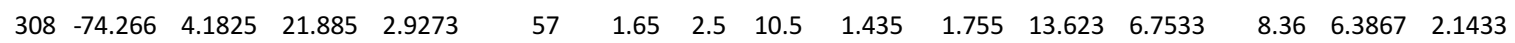
$\begin{array}{llllllllllllllll}310 & -74.27 & 4.1778 & 30.497 & 3.8677 & 76.333 & 2.4333 & 2.5 & 21 & 2.89 & 1.7525 & 10.407 & 6.3867 & 8.8733 & 5.8433 & 2.0033\end{array}$

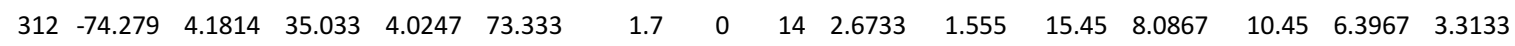

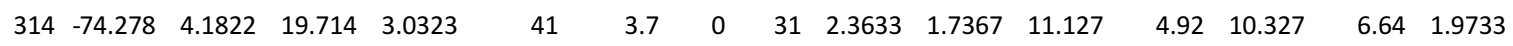

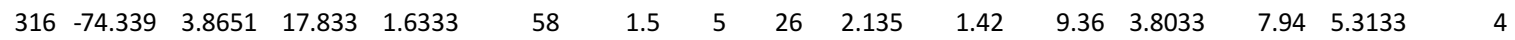

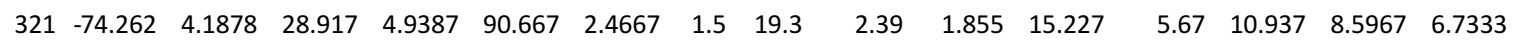


Pineda Yam Pineda Yam Pineda Yam Pineda Yam Pineda Yam Pineda Yam Pineda Yam Pineda Yam Pineda Yam Pineda Yam Pineda Yam Pineda Yam Pineda Yam Pineda Yam Pineda Yam Pineda Yam Pineda Yam Pineda Yam Pineda Yam Pineda Yam Pineda Yam Pineda Yam Pineda Yam Pineda Yam Pineda Yam Pineda Yam Pineda Yam Pineda Yam Pineda Yam Pineda Yam Pineda Yam Pineda Yam Pineda Yam Pineda Yam Pineda Yam Pineda Yam Pineda Yam Pineda Yam Pineda Yam Pineda Yam Pineda Yam Pineda Yam Pineda Yam Pineda Yam Pineda Yam Pineda Yam Pineda Yam Pineda Yam Pineda Yam Pineda Yam Pineda Yam Pineda Yam Pineda Yam Pineda Yam Pineda Yam Pineda Yam Pineda Yam Pineda Yam Pineda Yam Pineda Yam Pineda Yam Pineda Yam $\begin{array}{lllllll}323 & -74.262 & 4.1878 & 21.774 & 3.0787 & 50.667 & 1.9\end{array}$ $\begin{array}{lllllll}325 & -74.269 & 4.1905 & 33.274 & 4.7367 & 50 & 2.4667\end{array}$ $\begin{array}{lllllll}328 & -74.269 & 4.1905 & 26.498 & 3.4603 & 62.333 & 1.4\end{array}$ $\begin{array}{lllllll}331 & -74.278 & 4.1903 & 38.34 & 2.7057 & 56.333 & 2.4667\end{array}$ $\begin{array}{rrrrrrr}337 & -74.277 & 4.1892 & 20.129 & 3.6927 & 52 & 1.5\end{array}$ $\begin{array}{lllllll}338 & -74.431 & 3.8214 & 22.565 & 3.1013 & 38.667 & 1.6333\end{array}$ $\begin{array}{lllllll}351 & -74.446 & 3.837 & 32.329 & 4.9177 & 60 & 1.9\end{array}$ $\begin{array}{llllllll}353 & -74.44 & 3.83 & 34.203 & 4.955 & 52.667 & 1.8\end{array}$ $\begin{array}{llllllll}355 & -74.425 & 3.8255 & 42.767 & 11.417 & 52.667 & 3.1667\end{array}$ $\begin{array}{llllllll}356 & -74.446 & 3.8309 & 32.827 & 4.198 & 48.25 & 1.9667\end{array}$ $\begin{array}{llllllll}364 & -74.295 & 4.2126 & 43.466 & 5.3627 & 106.33 & 2.0333\end{array}$ $\begin{array}{lllllll}378 & -74.335 & 3.8339 & 30.202 & 3.861 & 43 & 1.7\end{array}$ $\begin{array}{llllllll}382 & -74.333 & 3.8255 & 38.41 & 4.4775 & 58.667 & 3.4333\end{array}$ $\begin{array}{lllllll}383 & -74.332 & 3.825 & 34.513 & 3.979 & 61 & 2.4667\end{array}$ $\begin{array}{lllllll}387 & -74.333 & 3.8247 & 33.245 & 5.9333 & 44 & 1.77\end{array}$ $\begin{array}{lllllll}388 & -74.333 & 3.8257 & 32.746 & 4.0383 & 54.667 & 2.2\end{array}$ $\begin{array}{llllllll}389 & -74.333 & 3.8257 & 33.5 & 4.343 & 41.333 & 3.1667\end{array}$ $\begin{array}{llllllll}394 & -74.29 & 4.2025 & 26.304 & 3.2633 & 72 & 2.0667\end{array}$ $\begin{array}{lllllll}396 & -74.29 & 4.2003 & 31.227 & 3.3157 & 85.333 & 1.7\end{array}$ $\begin{array}{llllllll}405 & -74.294 & 4.1989 & 44.095 & 5.2633 & 93.667 & 2.5\end{array}$ $\begin{array}{lllllll}410 & -74.22 & 4.2836 & 31.785 & 4.363 & 75 & 2\end{array}$ $\begin{array}{llllllll}411 & -74.288 & 4.2124 & 43.371 & 3.547 & 143 & 1.9667\end{array}$ $\begin{array}{lllllll}412 & -74.296 & 4.2043 & 24.75 & 3.4353 & 81 & 2.5\end{array}$ $\begin{array}{lllllll}413 & -74.3 & 4.2005 & 42.379 & 5.572 & 121.67 & 2.3\end{array}$ $\begin{array}{llllllll}414 & -74.293 & 4.2178 & 46.474 & 5.6867 & 107.33 & 2.3667\end{array}$ $\begin{array}{llllllll}415 & -74.291 & 4.2097 & 46.783 & 3.7163 & 83.333 & 2.7667\end{array}$ $\begin{array}{llllllll}416 & -74.291 & 4.2023 & 25.205 & 2.7517 & 57.333 & 1.3333\end{array}$ $\begin{array}{rrrrrrr}417 & -74.29 & 4.2004 & 32.804 & 3.7837 & 83 & 2.75\end{array}$ $\begin{array}{lllllll}418 & -74.29 & 4.2004 & 37.412 & 4.434 & 78.667 & 2.2333\end{array}$ $\begin{array}{llllllll}420 & -74.221 & 4.2833 & 34.044 & 5.0847 & 71.333 & 2.0333\end{array}$ $\begin{array}{lllllll}468 & -74.189 & 4.2928 & 18.03 & 2.813 & 40.333 & 1.7\end{array}$ $\begin{array}{llllllll}487 & -74.203 & 4.2764 & 19.891 & 3.0947 & 57.333 & 2.1\end{array}$ $\begin{array}{lllllll}497 & -74.188 & 4.2928 & 19.35 & 2.8897 & 43.5 & 1.7\end{array}$ $\begin{array}{llllllll}506 & -74.253 & 4.0378 & 37.546 & 3.8313 & 56.667 & 2.1\end{array}$ $\begin{array}{lllllll}511 & -74.255 & 4.0536 & 24.89 & 2.7413 & 67 & 1.7333\end{array}$ $\begin{array}{lllllll}519 & -74.266 & 4.0414 & 24.734 & 3.06 & 47 & 2.1333\end{array}$ $\begin{array}{llllllll}521 & -74.266 & 4.0414 & 28.089 & 4.3087 & 53.333 & 1.5333\end{array}$ $\begin{array}{rllllll}525 & -74.266 & 4.0414 & 23.785 & 3.4347 & 41 & 1.9667\end{array}$ $\begin{array}{llllllll}535 & -74.337 & 3.8213 & 27.883 & 4.2163 & 49.667 & 2\end{array}$ $\begin{array}{lllllll}538 & -74.336 & 3.8139 & 23.17 & 3.3847 & 46 & 4.2333\end{array}$ $\begin{array}{lllllll}544 & -74.338 & 3.8105 & 26.402 & 4.556 & 55.5 & 2.3\end{array}$ $\begin{array}{llllllll}545 & -74.338 & 3.8107 & 23.371 & 4.5987 & 49.333 & 2.4667\end{array}$ $\begin{array}{lllllll}546 & -74.338 & 3.8112 & 33.382 & 3.233 & 48.667 & 3.7\end{array}$ $\begin{array}{llllllll}549 & -74.331 & 3.8138 & 35.161 & 5.6687 & 64.333 & 3\end{array}$ $\begin{array}{llllllll}550 & -74.335 & 3.8039 & 33.963 & 4.308 & 62.333 & 2.1333\end{array}$ $\begin{array}{lllllll}561 & -74.169 & 4.2939 & 22.36 & 2.9193 & 41.667 & 2\end{array}$ $\begin{array}{llllllll}601 & -74.439 & 3.8142 & 42.587 & 3.484 & 57.333 & 2.3333\end{array}$ $\begin{array}{lllllll}602 & -74.439 & 3.8142 & 35.306 & 4.0333 & 90.5 & 2.7667\end{array}$ $\begin{array}{lllllll}603 & N A & \text { NA } & 40.196 & 5.182 & 59.833 & 1.6667\end{array}$ $\begin{array}{lllllll}606 & -74.439 & 3.8142 & 33.163 & 3.695 & 47 & 1.5333\end{array}$ $\begin{array}{llllllll}609 & -74.439 & 3.8139 & 31.035 & 4.0827 & 50.667 & 1.8\end{array}$ $\begin{array}{llllllll}613 & -74.445 & 3.8078 & 30.257 & 6.1363 & 51.333 & 1.8667\end{array}$ $\begin{array}{lllllll}615 & -74.436 & 3.8055 & 38.284 & 7.213 & 61 & 1.8333\end{array}$ $\begin{array}{lllllll}619 & -74.433 & 3.8062 & 27.942 & 2.722 & 59 & 3.2\end{array}$ $\begin{array}{lllllll}620 & -74.432 & 3.8062 & 7.093 & 1.175 & 52.25 & 4.45\end{array}$ $\begin{array}{llllllll}633 & -74.335 & 3.8035 & 30.461 & 3.7897 & 51.333 & 1.7667\end{array}$ $\begin{array}{lllllll}638 & -74.205 & 4.2995 & 26.423 & 3.4107 & 55.5 & 2.05\end{array}$ $\begin{array}{llllllll}644 & -74.212 & 4.307 & 22.911 & 3.881 & 58.5 & 2.25\end{array}$ $\begin{array}{lllllll}646 & -74.213 & 4.3056 & 18.738 & 2.5413 & 48 & 1.3\end{array}$ $\begin{array}{llllllll}650 & -74.201 & 4.2991 & 27.031 & 4.3177 & 69.333 & 2.7333\end{array}$ $\begin{array}{llllllll}685 & -74.206 & 4.2974 & 41.971 & 4.19 & 76.333 & 2.6333\end{array}$ $\begin{array}{lllllll}686 & -74.212 & 4.307 & 24.378 & 3.3033 & 52.667 & 1.6333\end{array}$ $\begin{array}{lllllllll}1 & 13 & 1.4783 & 1.4925 & 10.987 & 7.45 & 10.177 & 6.0367 & 1.6967\end{array}$ $\begin{array}{lllllllll}1 & 6.33 & 1.966 & 2.0025 & 22.03 & 12.107 & 13.577 & 7.68 & 2.74\end{array}$ $\begin{array}{lllllllll}2 & 9.67 & 2.3233 & 2.18 & 13.293 & 7.0267 & 9.56 & 6.6667 & 2.1767\end{array}$ $\begin{array}{rrrrrrrrr}0 & 5 & 4.8467 & 2.8925 & 19.127 & 15.1 & 13.97 & 8.2 & 1.85\end{array}$ $\begin{array}{llllllllll}2 & 10 & 2.5433 & 1.3675 & 9.31 & 5.0833 & 8.2267 & 5.6233 & 2.01\end{array}$ $\begin{array}{lllllllll}0 & 8 & 2.155 & 1.59 & 14.237 & 3.0333 & 9.2733 & 5.67 & 4.38\end{array}$ $\begin{array}{lrrrrrrrr}0 & 20.3 & 1.7133 & 1.7 & 11.51 & 3.02 & 11.257 & 5.7633 & 4\end{array}$ $\begin{array}{llrlrllll}0 & 13.7 & 3.78 & 1.6225 & 13.043 & 2.7467 & 8.6967 & 6.8867 & 5.09\end{array}$ $\begin{array}{rrrrrrrrrr}2.5 & 13 & 3.9133 & 2.49 & 20.07 & 13.297 & 15.717 & 11.483 & 5.1467\end{array}$ $\begin{array}{lllllllll}0 & 10 & 2.5717 & 1.955 & 11.57 & 2.6367 & 7.8767 & 5.96 & 4.2133\end{array}$ $\begin{array}{llllllllll}1 & 13.3 & 1.71 & 1.795 & 13.973 & 6.0833 & 9.3067 & 7.84 & 4.9033\end{array}$ $\begin{array}{lllllllll}0 & 7.67 & 2.2867 & 2.375 & 12.37 & 4.275 & 11.14 & 7.5267 & 2.14\end{array}$ $\begin{array}{llllllllll}0 & 3 & 21.467 & 3.7425 & 34.72 & 13.49 & 12.59 & 9.5667 & 6.54\end{array}$ $\begin{array}{lllllllll}0 & 3 & 9.4167 & 3.525 & 20.42 & 6.44 & 12.96 & 8.2567 & 1.51\end{array}$ $\begin{array}{lllllllll}0 & 9 & 9.3783 & 2.685 & 23.76 & 6.5667 & 12.753 & 8.1333 & 2.6\end{array}$ $\begin{array}{llllllllll}1 & 14.7 & 2.3517 & 1.65 & 11.323 & 5.4167 & 11.177 & 7.5333 & 5.1333\end{array}$ $\begin{array}{lllllllll}0 & 6.33 & 6.0817 & 1.8225 & 18.91 & 7.6033 & 13.567 & 7.5 & 2.19\end{array}$ $\begin{array}{lllllllll}1 & 12.3 & 1.1867 & 1.6938 & 8.96 & 4.67 & 8.93 & 6.3167 & 3.5833\end{array}$ $\begin{array}{lllllllll}1 & 11 & 2.05 & 1.65 & 9.9867 & 3.8633 & 10.09 & 6.15 & 4.2533\end{array}$ $\begin{array}{llllllllll}0 & 15.3 & 2.66 & 1.2263 & 12.587 & 5.9933 & 8.6233 & 6.5833 & 1.9333\end{array}$ $\begin{array}{llllllllll}0 & 6.5 & 6.225 & 3.15 & 19.993 & 13.49 & 25.503 & 10.483 & 2.8833\end{array}$ $\begin{array}{llllllllll}1.5 & 28 & 1.66 & 1.54 & 10.087 & 4.6167 & 7.7633 & 6.2133 & 2.7267\end{array}$ $\begin{array}{rrrrrrrrr}3.5 & 50 & 2.3333 & 1.5725 & 12.287 & 5.4467 & 9.7933 & 7.6 & 4.3067\end{array}$ $\begin{array}{lllllllll}0 & 22.3 & 1.9517 & 1.64 & 13.2 & 5.89 & 10.037 & 7.8067 & 2.6233\end{array}$ $\begin{array}{lllllllll}0 & 25.3 & 2.5533 & 1.6925 & 12.323 & 6.52 & 10.493 & 6.37 & 2.5433\end{array}$ $\begin{array}{lllllllll}0 & 5 & 8.7833 & 2.83 & 20.797 & 14.03 & 17.113 & 8.5367 & 2.19\end{array}$ $\begin{array}{rrrrrrrrr}1 & 7 & 2.1567 & 1.44 & 8.8067 & 3.49 & 9.3433 & 6.0233 & 2.6067\end{array}$ $\begin{array}{llllllllll}1 & 6.5 & 6.072 & 2.8525 & 21.237 & 14.893 & 16.153 & 10.473 & 2.9567\end{array}$ $\begin{array}{llllllllll}0 & 10 & 2.3917 & 1.5575 & 12.533 & 7.9067 & 9.1833 & 6.5533 & 2.26\end{array}$ $\begin{array}{llllllllll}4 & 9.33 & 1.88 & 1.9025 & 14.077 & 9.5033 & 10.923 & 6.3667 & 1.9467\end{array}$ $\begin{array}{lllllllll}0 & 6.33 & 2.816 & 2.1375 & 14.207 & 6.26 & 10.73 & 6.6733 & 5.8533\end{array}$ $\begin{array}{lllllllll}0 & 12 & 3.6067 & 1.84 & 9.27 & 4.2667 & 8.3333 & 5.38 & 4.68\end{array}$ $\begin{array}{lllllllll}0 & 11 & 1.615 & 1.7288 & 9.39 & 4.37 & 11.32 & 6.8367 & 2.2667\end{array}$ $\begin{array}{lllllllll}0 & 3 & 4.6783 & 3.27 & 24.29 & 4.8967 & 14.957 & 7.4733 & 1.8633\end{array}$ $\begin{array}{lllllllll}1 & 17.3 & 2.7467 & 1.4425 & 14.163 & 6.01 & 10.027 & 5.99 & 2.0333\end{array}$ $\begin{array}{lllllllll}0 & 14.7 & 2.3817 & 2.0538 & 11.28 & 5.11 & 9.0933 & 6.57 & 1.6933\end{array}$ $\begin{array}{lllllllll}0 & 4 & 3.8017 & 2.0925 & 10.74 & 5.47 & 8.9833 & 6.5767 & 2.0133\end{array}$ $\begin{array}{llllllllll}2 & 11.7 & 1.9233 & 1.59 & 10.827 & 4.97 & 10.893 & 6.2567 & 1.8067\end{array}$ $\begin{array}{lllllllll}0 & 3 & 4.915 & 2.85 & 19.543 & 4.62 & 17.023 & 9.55 & 1.9733\end{array}$ $\begin{array}{llllllllll}0 & 7.33 & 6.3367 & 2.89 & 21.747 & 4.7367 & 10.35 & 7.0433 & 5.0767\end{array}$ $\begin{array}{llllllllll}3 & 14 & 1.625 & 2.13 & 11.703 & 7.2333 & 15.813 & 6.1933 & 1.5367\end{array}$ $\begin{array}{lllllllll}3.5 & 9.33 & 1.2517 & 1.185 & 12.883 & 9.5167 & 11.61 & 7.3333 & 5.89\end{array}$ $\begin{array}{lllllllll}0 & 9 & 10.212 & 2.185 & 17.2 & 8.04 & 11.4 & 8.04 & 5.4533\end{array}$ $\begin{array}{llllllllll}2 & 15.7 & 2.455 & 2.3025 & 13.563 & 5.7167 & 11.417 & 6.79 & 2.8167\end{array}$ $\begin{array}{lllllllll}1 & 16 & 2.4467 & 1.7333 & 12.41 & 4.2267 & 11.783 & 6.3433 & 2.1833\end{array}$ $\begin{array}{lllllllll}1 & 7 & 1.85 & 1.3825 & 8.3623 & 3.84 & 8.76 & 5.9 & 2.3333\end{array}$ $\begin{array}{lllllllll}0 & 3 & 11.533 & 3.27 & 29.04 & 8.96 & 15.493 & 8.86 & 1.9367\end{array}$ $\begin{array}{lllllllll}4 & 14.3 & 3.935 & 1.7525 & 13.367 & 9.06 & 10.777 & 6.13 & 2.05\end{array}$ $\begin{array}{lllllllll}0 & 12 & 1.9717 & 1.5925 & 9.74 & 3.93 & 8.72 & 6.6333 & 1.69\end{array}$ $\begin{array}{lllllllll}0 & 9.33 & 3.035 & 1.525 & 8.7967 & 2.88 & 7.58 & 5.73 & 1.53\end{array}$ $\begin{array}{llllllllll}0 & 8.67 & 2.25 & 1.82 & 10.493 & 3.4633 & 9.4933 & 5.4133 & 2.1567\end{array}$ $\begin{array}{lllllllll}0 & 13 & 1.8783 & 1.75 & 12.3 & 4.3 & 9.2333 & 5.9367 & 1.9967\end{array}$ $\begin{array}{lllllllll}0 & 15.3 & 2.3117 & 1.655 & 12.02 & 1.9567 & 7.3667 & 5.9433 & 2.2033\end{array}$ $\begin{array}{lllllllll}1 & 84 & 2.6617 & 1.3375 & 8.4267 & 3.1 & 9.02 & 5.49 & 5.0767\end{array}$ $\begin{array}{llllllllll}0 & 25 & 1.926 & 1.9175 & 10.213 & 3.5833 & 7.7 & 6.0467 & 5.0833\end{array}$ $\begin{array}{llllllllll}0 & 13 & 1.745 & 1.5688 & 13.297 & 3.0467 & 8.2867 & 5.6667 & 1.64\end{array}$ $\begin{array}{lllllllll}0 & 11 & 1.755 & 1.7125 & 10.127 & 4.87 & 8.8967 & 6.46 & 5.0333\end{array}$ $\begin{array}{lllllllll}0 & 12.5 & 2.22 & 1.775 & 10.853 & 4.27 & 10.72 & 6.1067 & 4.6\end{array}$ $\begin{array}{lllllllll}1 & 6 & 0.94 & 1.3867 & 10.26 & 5.4433 & 9.03 & 4.9733 & 1.4767\end{array}$ $\begin{array}{lllllllll}2 & 19 & 3.206 & 1.7825 & 8.4233 & 3.9033 & 11.627 & 5.34 & 4.55\end{array}$ $\begin{array}{lllllllll}0 & 5 & 6.8 & 3.0225 & 24.077 & 14.48 & 17.2 & 8.59 & 6.8933\end{array}$ $\begin{array}{lllllllll}0 & 7 & 3.0017 & 1.5025 & 8.84 & 4.56 & 10.627 & 6.06 & 5.88\end{array}$ 
Pineda Yam Pineda Yam Pineda Yam Pineda Yam Pineda Yam Pineda Yam Pineda Yam Pineda Yam Pineda Yam Pineda Yam Pineda Yam Pineda Yam Pineda Yam Pineda Yam Pineda Yam Pineda Yam Pineda Yam Pineda Yam Pineda Yam Pineda Yam Pineda Yam Pineda Yam Pineda Yam Pineda Yam Pineda Yam Pineda Yam Pineda Yam Pineda Yam Pineda Yam Pineda Yam Pineda Yam Pineda Yam Pineda Yam Pineda Yam Pineda Yam Pineda Yam Pineda Yam Pineda Yam Pineda Yam Pineda Yam Pineda Yam Pineda Yam Pineda Yam Pineda Yam Pineda Yam Pineda Yam Pineda Yam Pineda Yam Pineda Yam Pineda Yam Pineda Yam Pineda Yam Pineda Yam Pineda Yam Pineda Yam Pineda Yam Pineda Yam Pineda Yam Pineda Yam Pineda Yam Pineda Yam Pineda Yam $\begin{array}{lllllll}690 & -74.213 & 4.3056 & 22.43 & 2.8377 & 43.333 & 1.2667\end{array}$ $\begin{array}{llllllll}694 & -74.256 & 4.0231 & 40.993 & 4.4607 & 72.333 & 2.5\end{array}$ $\begin{array}{llllllll}706 & -74.265 & 4.0513 & 36.932 & 6.3313 & 53.667 & 2.5667\end{array}$ $\begin{array}{lllllll}707 & -74.265 & 4.0513 & 29.672 & 3.966 & 73.5 & 2.25\end{array}$ $\begin{array}{llllllll}709 & -74.264 & 4.0475 & 31.425 & 6.045 & 56.667 & 2.0667\end{array}$ $\begin{array}{lllllll}713 & -74.262 & 4.0458 & 30.64 & 4.487 & 63 & 2.5333\end{array}$ $\begin{array}{lllllll}717 & -74.249 & 4.0189 & 42.01 & 3.5863 & 65.333 & 2.2\end{array}$ $\begin{array}{lllllll}719 & -74.25 & 4.023 & 25.446 & 2.5453 & 60 & 2.2667\end{array}$ $\begin{array}{llllllll}721 & -74.25 & 4.023 & 30.29 & 2.9127 & 49.667 & 2.8333\end{array}$ $\begin{array}{lllllll}722 & -74.25 & 4.023 & 25.219 & 2.485 & 37 & 3.5333\end{array}$ $\begin{array}{llllllll}724 & -74.261 & 4.0475 & 35.487 & 6.23 & 85.667 & 3.0667\end{array}$ $\begin{array}{llllllll}726 & -74.261 & 4.0475 & 35.45 & 4.061 & 74.667 & 1.6667\end{array}$ $\begin{array}{llllllll}731 & -74.255 & 4.02 & 31.351 & 3.4927 & 66.333 & 2.7\end{array}$ $\begin{array}{llllllll}734 & -74.26 & 4.0252 & 21.513 & 3.3523 & 45.667 & 2.3667\end{array}$ $\begin{array}{llllllll}737 & -74.26 & 4.0324 & 18.144 & 2.7737 & 50.667 & 2.3333\end{array}$ $\begin{array}{llllllll}738 & -74.261 & 4.0325 & 24.177 & 2.7027 & 49.667 & 2.2333\end{array}$ $\begin{array}{lllllll}742 & -74.258 & 4.0364 & 27.12 & 3.7307 & 51 & 2.7333\end{array}$ $\begin{array}{llllllll}744 & -74.267 & 4.0405 & 31.396 & 7.4333 & 74.333 & 2.8667\end{array}$ $\begin{array}{llllllll}745 & -74.267 & 4.0402 & 33.16 & 6.1333 & 67.667 & 3.6333\end{array}$ $\begin{array}{lllllll}746 & -74.271 & 4.0383 & 24.452 & 4.8 & 50.333 & 2.1\end{array}$ $\begin{array}{lllllll}748 & -74.271 & 4.0383 & 23.695 & 2.9 & 41 & 1.6333\end{array}$ $\begin{array}{llllllll}749 & -74.271 & 4.0383 & 21.709 & 3.1667 & 57 & 1.9\end{array}$ $\begin{array}{lllllll}750 & -74.271 & 4.0383 & 34.261 & 5.2333 & 92 & 2.2333\end{array}$ $\begin{array}{lllllll}751 & -74.427 & 3.8296 & 38.609 & 9.65 & 77.5 & 4.2\end{array}$ $\begin{array}{llllllll}753 & -74.427 & 3.8256 & 30.182 & 5.6 & 58 & 2.15\end{array}$ $\begin{array}{lllllll}755 & -74.424 & 3.8283 & 46.232 & 4.4 & 55 & 2.1\end{array}$ $\begin{array}{llllllll}757 & -74.422 & 3.8292 & 31.968 & 4.2333 & 66.667 & 1.9667\end{array}$ $\begin{array}{llllllll}761 & -74.418 & 3.8203 & 30.718 & 4.4333 & 63.5 & 2.3333\end{array}$ $\begin{array}{llllllll}774 & -74.427 & 3.8081 & 31.521 & 5.2333 & 53.667 & 1.9667\end{array}$ $\begin{array}{llllllll}776 & -74.427 & 3.8081 & 36.874 & 7.1665 & 84.667 & 2.9\end{array}$ $\begin{array}{llllllll}782 & -74.425 & 3.8033 & 30.934 & 3.694 & 61.667 & 1.9\end{array}$ $\begin{array}{lllllll}788 & -74.26 & 4.065 & 31.003 & 3.853 & 53 & 3.1333\end{array}$ $\begin{array}{llllllll}789 & -74.26 & 4.0669 & 26.189 & 3.457 & 54.667 & 2.6333\end{array}$ $\begin{array}{llllllll}792 & -74.258 & 4.0735 & 36.548 & 7.907 & 75.667 & 2.3667\end{array}$ $\begin{array}{lllllll}795 & -74.268 & 4.0583 & 30.63 & 5.3107 & 41.333 & 2\end{array}$ $\begin{array}{llllllll}797 & -74.26 & 4.0769 & 38.639 & 4.7573 & 52.333 & 1.9667\end{array}$

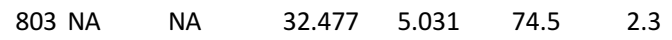
$\begin{array}{llllll}804 \mathrm{NA} & \text { NA } & 22.208 & 3.5273 & 56.45 & 1.75\end{array}$

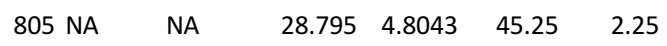

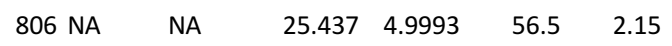
$\begin{array}{llllllll}807 & -74.266 & 4.0606 & 27.657 & 5.1497 & 62.5 & 2.2\end{array}$ $\begin{array}{lllllll}808 & -74.266 & 4.0606 & 20.247 & 2.701 & 46 & 1.8\end{array}$ $\begin{array}{llllllll}812 & -74.266 & 4.0606 & 28.012 & 4.841 & 39.667 & 5.9\end{array}$ $\begin{array}{llllllll}814 & -74.266 & 4.0605 & 34.555 & 4.5173 & 64.667 & 2.7\end{array}$ $\begin{array}{llllllll}820 & -74.268 & 4.0608 & 36.917 & 4.6207 & 68.333 & 3.1667\end{array}$ $\begin{array}{lllllll}822 & -74.268 & 4.0608 & 30.749 & 3.235 & 49.667 & 2.1667\end{array}$ $\begin{array}{lllllll}823 & -74.268 & 4.0522 & 35.082 & 4.703 & 53 & 2.9333\end{array}$ $\begin{array}{llllllll}824 & -74.269 & 4.0597 & 35.483 & 3.913 & 79.667 & 2.8667\end{array}$ $\begin{array}{rrrrrrr}825 & -74.27 & 4.0575 & 40.465 & 6.0497 & 68 & 3\end{array}$ $\begin{array}{llllllll}826 & -74.27 & 4.0575 & 21.412 & 3.6583 & 51.667 & 2.3333\end{array}$ $\begin{array}{lllllll}828 & -74.269 & 4.0572 & 19.726 & 3.2293 & 41 & 2.1333\end{array}$ $\begin{array}{llllllll}830 & -74.201 & 4.2782 & 25.921 & 4.0477 & 66.667 & 1.7\end{array}$ $\begin{array}{llllllll}831 & -74.198 & 4.2822 & 41.067 & 4.5927 & 91.267 & 2.8\end{array}$ $\begin{array}{lllllll}834 & -74.202 & 4.187 & 32.532 & 1.873 & 74 & 1.6333\end{array}$ $\begin{array}{llllllll}835 & -74.265 & 4.1825 & 37.042 & 4.46 & 75.333 & 2.4667\end{array}$ $\begin{array}{lllllll}836 & -74.226 & 4.1862 & 33.387 & 2.1717 & 84 & 1.7667\end{array}$ $\begin{array}{llllllll}838 & -74.237 & 4.1375 & 33.986 & 4.422 & 60.833 & 2.5333\end{array}$ $\begin{array}{llllllll}840 & -74.247 & 4.2129 & 39.336 & 4.8983 & 69.667 & 2.8667\end{array}$ $\begin{array}{llllllll}841 & -74.247 & 4.2129 & 27.787 & 3.1367 & 67.333 & 2.0667\end{array}$ $\begin{array}{llllllll}842 & -74.247 & 4.2123 & 32.911 & 3.0477 & 61.333 & 2.1333\end{array}$ $\begin{array}{lllllll}846 & -74.404 & 3.8555 & 34.664 & 4.133 & 63.5 & 2.4\end{array}$ $\begin{array}{lllllll}848 & -74.425 & 3.8256 & 34.138 & 8.7127 & 67.5 & 3.05\end{array}$ $\begin{array}{lllllllll}0 & 8.67 & 1.55 & 1.69 & 9.9867 & 5.4 & 11.837 & 5.3167 & 4.89\end{array}$ $\begin{array}{lllllllll}0 & 3 & 9.7667 & 3.8625 & 19.22 & 6.2 & 11.853 & 6.9167 & 5.5933\end{array}$ $\begin{array}{lllllllll}1 & 12 & 2.9167 & 2.0971 & 19.413 & 10.523 & 10.147 & 7.53 & 5.1433\end{array}$ $\begin{array}{lllllllll}2 & 5.5 & 2.575 & 1.93 & 17.23 & 8.7667 & 11.4 & 8.41 & 3.1367\end{array}$ $\begin{array}{lllllllll}0 & 10.7 & 3.535 & 2.105 & 10.5 & 5.7 & 7.54 & 6.16 & 2.0133\end{array}$ $\begin{array}{llllllllll}0 & 13.3 & 2.2375 & 1.7825 & 9.4133 & 3.6067 & 8.1867 & 5.9533 & 2.1267\end{array}$ $\begin{array}{lllllllll}0 & 3 & 7.7333 & 3.405 & 22.4 & 7.24 & 15.58 & 7.905 & 7.305\end{array}$ $\begin{array}{lllllllll}3 & 16.3 & 2.28 & 2.155 & 17.363 & 8.0933 & 10.63 & 6.9633 & 5.8667\end{array}$ $\begin{array}{lllllllll}2 & 14.3 & 1.7683 & 1.4167 & 13.563 & 9.9133 & 11.2 & 6.4433 & 2.3133\end{array}$ $\begin{array}{llllllllll}0 & 8 & 5.335 & 2.8175 & 15.5 & 6.4067 & 11.527 & 7.9233 & 5.6467\end{array}$ $\begin{array}{lllllllll}0 & 20 & 1.665 & 1.8125 & 11.287 & 3.9067 & 7.5867 & 6.11 & 4.3667\end{array}$ $\begin{array}{lllllllll}0 & 25.3 & 1.615 & 1.34 & 7.5433 & 4.6333 & 5.6 & 4.4333 & 4.43\end{array}$ $\begin{array}{lllllllll}2 & 10.7 & 2.3983 & 1.8505 & 15.57 & 8.0867 & 8.26 & 5.6 & 1.3067\end{array}$ $\begin{array}{llllllllll}2 & 9.67 & 1.7017 & 1.435 & 12.18 & 5.7667 & 7.23 & 5.2667 & 1.9067\end{array}$ $\begin{array}{lllllllll}2 & 14.3 & 2.44 & 1.6125 & 13.103 & 5.94 & 11.413 & 6.2733 & 2.0233\end{array}$ $\begin{array}{lllllllll}2 & 8.67 & 1.6267 & 1.73 & 12.477 & 8.1133 & 11.117 & 6.25 & 1.97\end{array}$ $\begin{array}{llllllllll}2 & 15 & 1.7817 & 1.725 & 12.563 & 7.7167 & 9.32 & 6.3433 & 2.0467\end{array}$ $\begin{array}{lllllllll}2 & 11.3 & 3.7417 & 1.9175 & 16.017 & 9.4733 & 12.84 & 7.9267 & 5.16\end{array}$ $\begin{array}{lllllllll}2 & 12.3 & 4.1233 & 1.705 & 16.343 & 9.19 & 10.933 & 7.6367 & 4.2333\end{array}$ $\begin{array}{llllllllll}0 & 11.5 & 1.8083 & 1.9125 & 12.447 & 6.1067 & 7.2 & 6.0767 & 2.0567\end{array}$ $\begin{array}{llllllllll}1 & 6.33 & 1.8817 & 1.7243 & 11.003 & 4.7167 & 13.31 & 5.8767 & 1.7333\end{array}$ $\begin{array}{lllllllll}0.5 & 13.3 & 2.43 & 1.605 & 11.273 & 4.82 & 8.1933 & 4.78 & 1.5233\end{array}$ $\begin{array}{llllllllll}0 & 14.7 & 2.39 & 1.8875 & 10.67 & 5.0933 & 9.1667 & 5.6733 & 1.2267\end{array}$ $\begin{array}{rrrrrrrrr}1.5 & 14 & 4.7 & 1.68 & 15.743 & 9.31 & 12.3 & 7.9133 & 5.3667\end{array}$ $\begin{array}{lllllllll}0 & 12 & 1.047 & 1.8675 & 8.0433 & 2.42 & 9.5533 & 6.4833 & 2.61\end{array}$ $\begin{array}{lllllllll}0 & 16.7 & 2.82 & 1.9175 & 10.197 & 2.97 & 8.65 & 6.0133 & 2.05\end{array}$ $\begin{array}{lllllllll}0 & 18.7 & 1.455 & 1.115 & 7.2533 & 2.3433 & 6.7467 & 5.72 & 1.7233\end{array}$ $\begin{array}{llllllllll}0 & 22.7 & 0.9333 & 1.225 & 8.48 & 2.9433 & 6.0267 & 6.1767 & 1.7333\end{array}$ $\begin{array}{lllllllll}0 & 17 & 1.8783 & 1.6 & 9.5567 & 3.81 & 8.4033 & 5.56 & 2.04\end{array}$ $\begin{array}{llllllllll}1 & 21.3 & 4.488 & 2.2413 & 12.56 & 5.9567 & 10.22 & 7.3933 & 5.71\end{array}$ $\begin{array}{llllllllll}0 & 16.7 & 1.2483 & 1.2225 & 9.1967 & 3.5267 & 6.5833 & 5.2467 & 1.9733\end{array}$ $\begin{array}{llllllllll}2 & 23.3 & 2.2767 & 1.325 & 9.32 & 5.0733 & 8.3733 & 5.9733 & 4.3933\end{array}$ $\begin{array}{lllllllll}4 & 16.3 & 2.3233 & 1.625 & 12.623 & 7.31 & 9.31 & 6.8633 & 4.8333\end{array}$ $\begin{array}{llllllllll}0 & 20.7 & 1.6017 & 1.925 & 11.327 & 6.24 & 8.7767 & 7.0167 & 3.1533\end{array}$ $\begin{array}{lllllllll}0 & 12 & 1.0133 & 1.655 & 11.37 & 6.9567 & 9.86 & 6.6067 & 2.2833\end{array}$ $\begin{array}{lllllrlrl}1 & 10 & 2.3517 & 1.7613 & 14.127 & 5.14 & 9.0433 & 6.14 & 4.7967\end{array}$ $\begin{array}{lllllllll}0 & 12 & 2.6167 & 2.0025 & 9.88 & 4.3067 & 8.4633 & 5.9433 & 1.7233\end{array}$ $\begin{array}{llllllllll}1 & 7.5 & 1.4283 & 2.035 & 11.393 & 4.8433 & 10.393 & 6.1033 & 1.6467\end{array}$ $\begin{array}{lllllllll}1 & 10.5 & 1.34 & 1.8386 & 11.06 & 5.77 & 8.03 & 5.94 & 1.41\end{array}$ $\begin{array}{lllllllll}0 & 9 & 1.432 & 2.0433 & 13.183 & 4.78 & 11.047 & 5.8833 & 1.5667\end{array}$ $\begin{array}{lllllllll}0 & 13.3 & 3.4317 & 1.655 & 12.697 & 5.8767 & 10.523 & 6.5633 & 1.9133\end{array}$ $\begin{array}{lllllllll}2 & 12.3 & 1.1083 & 1.6675 & 13.947 & 6.9 & 9.8433 & 6.56 & 1.7167\end{array}$ $\begin{array}{rrrrrrrrrr}0 & 6 & 7.845 & 2.7 & 16.453 & 9.6467 & 13.163 & 7.57 & 1.8367\end{array}$ $\begin{array}{lllllllll}0 & 3 & 20.25 & 3.5375 & 32.2 & 11.543 & 18.07 & 9.1533 & 2.4367\end{array}$ $\begin{array}{lllllllll}0 & 3 & 12 & 2.75 & 26.427 & 8.2867 & 13.04 & 7.6867 & 2.1267\end{array}$ $\begin{array}{lllllllll}2 & 15.3 & 2.8483 & 1.63 & 13.987 & 9.2933 & 9.14 & 6.58 & 2.6233\end{array}$ $\begin{array}{llllllllll}0 & 3 & 13.917 & 3.7575 & 32.597 & 9.2833 & 17.683 & 8.6333 & 2.4133\end{array}$ $\begin{array}{lllllllll}0 & 3 & 12.083 & 3.6275 & 21.157 & 6.6067 & 13.493 & 7.96 & 1.6633\end{array}$ $\begin{array}{llllllllll}0 & 3 & 9.6667 & 3.775 & 26.573 & 9.4967 & 17.597 & 8.35 & 2.11\end{array}$ $\begin{array}{llllllllll}2 & 15 & 1.74 & 1.375 & 13.133 & 8.0933 & 13.983 & 6.6167 & 2.6933\end{array}$ $\begin{array}{lllllllll}2 & 12 & 1.6833 & 1.4 & 13.007 & 6.0633 & 11.79 & 6.1767 & 2.32\end{array}$ $\begin{array}{lllllllll}1 & 9.67 & 2.575 & 2.3975 & 14.637 & 5.63 & 9.5167 & 6.21 & 1.6733\end{array}$ $\begin{array}{lllllllll}0 & 6.67 & 3.3733 & 2.72 & 22.57 & 11.247 & 13.54 & 8.9 & 2.1467\end{array}$ $\begin{array}{lllllllll}2 & 13.3 & 0.61 & 0.7675 & 4.1933 & 3.3367 & 4.02 & 2.05 & 1.0233\end{array}$ $\begin{array}{llllllllll}3 & 13.7 & 1.86 & 2.0475 & 15.893 & 6.4033 & 10.917 & 6.3367 & 1.87\end{array}$ $\begin{array}{lllllllll}3.5 & 13.3 & 0.9333 & 1.0075 & 5.2 & 2.8767 & 6.15 & 3.41 & 1.785\end{array}$ $\begin{array}{lllllllll}3 & 11.7 & 1.74 & 1.81 & 11.393 & 4.78 & 7.83 & 5.1867 & 1.5433\end{array}$ $\begin{array}{lllllllll}0 & 5 & 6.8283 & 3.45 & 25.947 & 17.377 & 23.527 & 10.497 & 3.9767\end{array}$ $\begin{array}{lllllllll}0 & 8.67 & 1.23 & 1.67 & 12.647 & 4.7933 & 8.5333 & 6.12 & 2.1433\end{array}$ $\begin{array}{lllllllll}0 & 6.33 & 2.0717 & 2.7275 & 16.613 & 12.313 & 11.233 & 7.6633 & 1.7433\end{array}$ $\begin{array}{llllllllll}0 & 23.3 & 1.9167 & 1.3275 & 9.3867 & 3.2067 & 5.2233 & 5.3067 & 1.67\end{array}$ $\begin{array}{lllllllll}2 & 30 & 3.535 & 2.1075 & 22.863 & 12.103 & 14.827 & 8.7467 & 2.5567\end{array}$ 
Pineda Yam Pineda Yam Pineda Yam Pineda Yam Pineda Yam Pineda Yam Pineda Yam Pineda Yam Pineda Yam Pineda Yam Pineda Yam Pineda Yam Pineda Yam Pineda Yam Pineda Yam Pineda Yam Pineda Yam Pineda Yam Pineda Yam Pineda Yam Pineda Yam Pineda Yam Pineda Yam Pineda Yam Pineda Yam Pineda Yam Pineda Yam Pineda Yam Pineda Yam Pineda Yam Pineda Yam Pineda Yam Pineda Yam Pineda Yam Pineda Yam Pineda Yam Pineda Yam Pineda Yam Pineda Yam Pineda Yam Pineda Yam Pineda Yam Pineda Yam Pineda Yam Pineda Yam Pineda Yam Pineda Yam Pineda Yam Pineda Yam Pineda Yam Pineda Yam Pineda Yam Pineda Yam Pineda Yam Pineda Yam Pineda Yam Pineda Yam Pineda Yam Pineda Yam Vergara Cuatrecasas Idrobo \& Hernar $\begin{array}{lllll}849 & -74.425 & 3.8256 & 38.741 & 10.346\end{array}$ $\begin{array}{lllll}850 & -74.425 & 3.8256 & 40.572 & 8.6567\end{array}$ $\begin{array}{lllll}851 & -74.425 & 3.8245 & 49.785 & 9.602\end{array}$ $\begin{array}{lllll}852 & -74.425 & 3.8243 & 33.556 & 4.435\end{array}$ $\begin{array}{lllll}853 & -74.432 & 3.8291 & 40.792 & 6.8407\end{array}$ $\begin{array}{lllll}854 & -74.432 & 3.8293 & 40.8 & 9.1787\end{array}$ $\begin{array}{lllll}855 & -74.432 & 3.8293 & 48.538 & 9.2647\end{array}$ $\begin{array}{lllll}856 & -74.432 & 3.8293 & 36.393 & 11.06\end{array}$ $\begin{array}{lllll}857 & -74.404 & 3.8582 & 33.62 & 2.3487\end{array}$ $\begin{array}{lllll}859 & -74.404 & 3.8584 & 32.298 & 2.9293\end{array}$ $\begin{array}{lllll}860 & -74.404 & 3.8583 & 40.119 & 2.482\end{array}$ $\begin{array}{lllll}861 & -74.404 & 3.8583 & 26.979 & 3.387\end{array}$ $\begin{array}{llllllll}862 & -74.404 & 3.8582 & 38.974 & 4.188 & 78.5 & 2.35\end{array}$ $\begin{array}{llllllll}864 & -74.336 & 3.8246 & 32.702 & 4.0017 & 61.333 & 2.4333\end{array}$ $\begin{array}{rrrrrrr}865 & -74.336 & 3.8246 & 29.662 & 4.2523 & 56 & 2.4\end{array}$ $\begin{array}{lllllll}866 & -74.336 & 3.8238 & 32.643 & 4.3693 & 79.833\end{array}$ $\begin{array}{lllllll}867 & -74.336 & 3.8233 & 27.314 & 3.299 & 54.667\end{array}$ $\begin{array}{lllllll}868 & -74.336 & 3.8231 & 30.35 & 3.816 & 66.833\end{array}$ $\begin{array}{lllllll}869 & -74.335 & 3.8229 & 36.651 & 4.354 & 52.833\end{array}$ $\begin{array}{lllllll}870 & -74.335 & 3.8225 & 32.905 & 3.9237 & 54.167\end{array}$

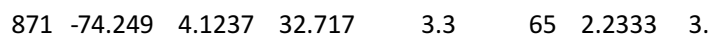
$\begin{array}{lllllll}872 & -74.294 & 4.0613 & 69.777 & 14.203 & 103.5 & 4.95\end{array}$ $\begin{array}{lllll}873 & -74.294 & 4.0611 & 36.279 & 7.4947\end{array}$ $\begin{array}{lllll}874 & -74.294 & 4.0866 & 36.618 & 3.474\end{array}$ $\begin{array}{lllll}875 & -74.257 & 4.0868 & 41.785 & 2.909\end{array}$ $\begin{array}{lllll}876 & -74.247 & 4.2111 & 32.577 & 3.8917\end{array}$ $\begin{array}{ll}62 & 2.4\end{array}$ $\begin{array}{ll}63 & 2.4333\end{array}$ $\begin{array}{ll}78 & 2.9333\end{array}$ $\begin{array}{lllllll}877 & -74.247 & 4.2117 & 53.003 & 4.321 & 65.5 & 3.25\end{array}$ $\begin{array}{lllllll}878 & -74.253 & 4.1954 & 33.812 & 3.351 & 61.667 & 2.8\end{array}$ $\begin{array}{lllllll}879 & -74.253 & 4.1953 & 32.807 & 3.342 & 72 & 2.3667\end{array}$ $\begin{array}{llllllll}880 & -74.253 & 4.1959 & 43.648 & 5.6557 & 71.333 & 2.6333\end{array}$ $\begin{array}{llllllll}881 & -74.252 & 4.1978 & 40.815 & 5.0277 & 98.333 & 2.9667\end{array}$ $\begin{array}{llllllll}882 & -74.247 & 4.2115 & 49.582 & 5.7007 & 89.667 & 3.7\end{array}$ $\begin{array}{llllllll}883 & -74.247 & 4.0611 & 48.476 & 3.0463 & 71.333 & 2.8\end{array}$ $\begin{array}{rrrrrrr}884 & -74.23 & 4.1834 & 38.499 & 5.3123 & 57 & 2.3333\end{array}$ $\begin{array}{llllllll}885 & -74.23 & 4.1835 & 38.779 & 5.4493 & 80.433 & 2.7\end{array}$ $\begin{array}{rrrrrrrrrrrrrrrr}886 & -74.231 & 4.1836 & 41.192 & 5.9617 & 91.667 & 2.5333 & 3.5 & 13.3 & 3.15 & 1.49 & 14.747 & 7.6867 & 13.827 & 8.2667 & 2.4533\end{array}$ $\begin{array}{llllllllllllllll}887 & -74.231 & 4.1837 & 40.318 & 5.4177 & 74 & 2.2333 & 2 & 15.3 & 3.3383 & 1.44 & 15.85 & 7.83 & 14.34 & 7.4 & 2.06\end{array}$

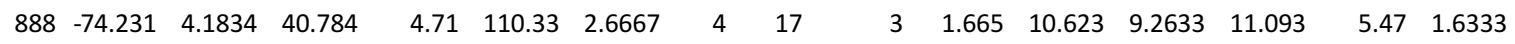
$\begin{array}{llllllllllllllll}889 & -74.229 & 4.1839 & 42.92 & 4.1533 & 99.667 & 2.7333 & 5.67 & 23.7 & 2.338 & 1.8525 & 16.727 & 8.3267 & 13.607 & 6.5967 & 1.8333\end{array}$

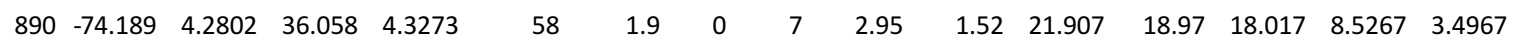

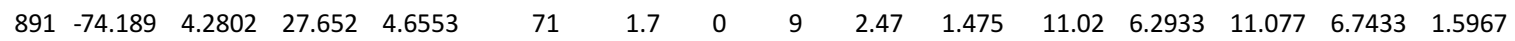

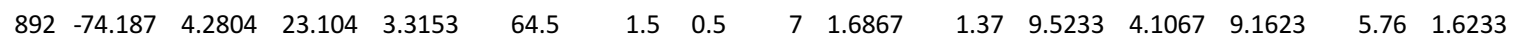

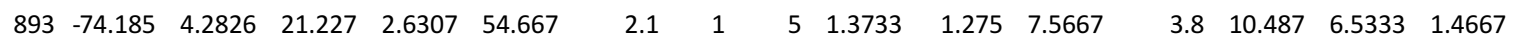

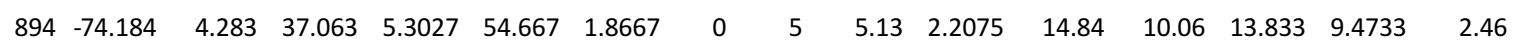

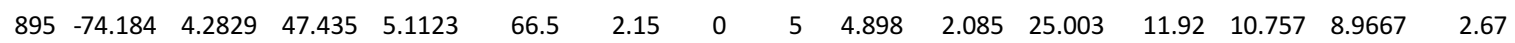

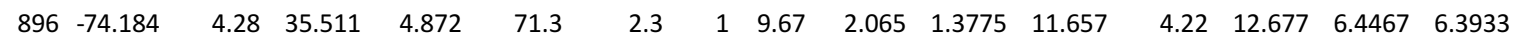
$\begin{array}{llllllllllllllll}897 & -74.183 & 4.2831 & 38.931 & 4.7607 & 75.667 & 2.9 & 0 & 7 & 3.3067 & 2.2275 & 15.233 & 10.75 & 19.603 & 9.4967 & 2.8433\end{array}$ $\begin{array}{llllllllllllllll}898 & -74.182 & 4.2825 & 36.384 & 5.1077 & 52.75 & 2.7 & 0 & 5 & 3.3933 & 2.3425 & 17.813 & 9.0267 & 11.75 & 8.3567 & 1.9433\end{array}$ $\begin{array}{llllllllllllllll}899 & -74.182 & 4.2825 & 42.341 & 5.6377 & 82.5 & 2.55 & 0 & 5 & 5.686 & 2.8175 & 20.75 & 11.277 & 15.087 & 9.7133 & 8.89\end{array}$ $\begin{array}{rlllllllllllllll}900 & -74.176 & 4.2839 & 40.568 & 4.162 & 61.55 & 1.9667 & 0 & 5 & 3.9017 & 2.1 & 16.453 & 13.053 & 16.767 & 9.6633 & 3.3167\end{array}$ $\begin{array}{llllllllllllllll}901 & -74.175 & 4.2847 & 35.213 & 4.4197 & 52.5 & 3.45 & 0 & 7 & 2.6333 & 1.8975 & 16.963 & 11.947 & 14.21 & 8.3667 & 2.3433\end{array}$

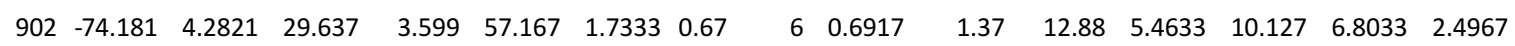

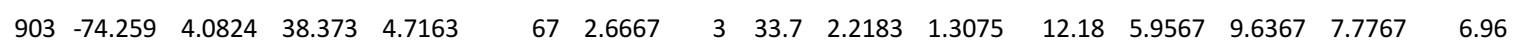
$\begin{array}{lllllllllllllllll}904 & -74.259 & 4.0824 & 45.002 & 6.4313 & 80.333 & 2.3667 & 0 & 14.3 & 4.6933 & 1.6525 & 12.327 & 5.6033 & 11.173 & 7.0333 & 2.76\end{array}$ $\begin{array}{rlllllllllllllll}905 & -74.253 & 4.0997 & 38.256 & 4.416 & 65.8 & 2.9667 & 2 & 12.7 & 2.8617 & 1.4675 & 11.893 & 6.6967 & 14.39 & 7.58 & 2.3967\end{array}$ $\begin{array}{llllllllllllllll}906 & -74.251 & 4.1094 & 38.453 & 3.917 & 84 & 2.1 & 3.67 & 22.3 & 3.6467 & 1.4225 & 9.7267 & 4.76 & 12.36 & 7.4767 & 2.1433\end{array}$ $\begin{array}{llllllllllllllll}907 & -74.249 & 4.1248 & 37.895 & 4.3863 & 63.833 & 2.5 & 3 & 13.3 & 3.1433 & 1.3925 & 10.423 & 4.2633 & 14.033 & 1.95 & 2.2067\end{array}$

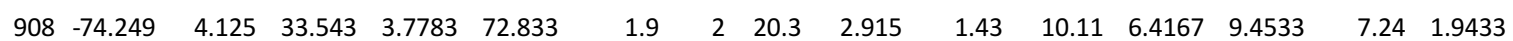
$\begin{array}{llllllllllllllll}909 & -74.241 & 4.1432 & 34.721 & 4.4543 & 83.3 & 3.0667 & 2.33 & 21.7 & 2.7017 & 1.5175 & 11.927 & 4.6067 & 13.237 & 5.91 & 1.8233\end{array}$

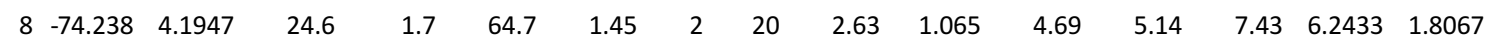
$\begin{array}{lllllllllllllll}27070 \mathrm{NA} & \text { NA } & 47.5 & 2.3033 & 85.5 & 1.7 & 3 & 16 & 1.68 & 1.272 & 6.2167 & 4.64 & 5.7933 & 4.965 & 2.03\end{array}$ 2756 NA NA
$41.1 \quad 2.075$
$134 \quad 2.2 \quad 3$ $\begin{array}{rrrrrrrrrrr}81.5 & 3.4 & 2 & 17 & 3.7633 & 2.2425 & 23.377 & 12.02 & 12.987 & 10.033 & 3.8933 \\ 71.5 & 3.615 & 0.5 & 28.5 & 2.185 & 2.12 & 19.553 & 10.453 & 11.683 & 9.0067 & 4.14\end{array}$ $\begin{array}{rrrrrrrrrrr}88.5 & 3.7 & 1.5 & 26.5 & 3.6383 & 2.1475 & 16.65 & 8.59 & 15.71 & 8.62 & 3.3033 \\ 69.25 & 2.3 & 0 & 14.5 & 0.9933 & 0.8725 & 9.7433 & 3.68 & 8.6733 & 5.9 & 2.1733\end{array}$

$\begin{array}{rrrrrrrrrrr}78.5 & 3 & 2 & 10.5 & 3.2133 & 2.1825 & 19.08 & 12.593 & 13.847 & 7.6333 & 3.1533\end{array}$ $\begin{array}{rrrrrrrrrrr}68 & 3.65 & 1 & 23.5 & 3.0283 & 2.2275 & 19.567 & 11.933 & 10.053 & 8.2567 & 3.14 \\ 92 & 4.15 & 2 & 22 & 1.6533 & 2.125 & 18.91 & 10.923 & 12.55 & 9.2133 & 4.7333\end{array}$ $\begin{array}{rrrrrrrrrrrr}94 & 3.8 & 2 & 36 & 5.29 & 2.0767 & 20.063 & 10.137 & 12.4 & 7.3933 & 2.5533 \\ 123 & 2.5 & 2 & 37.3 & 3.7133 & 0.8375 & 4.5133 & 2.8667 & 5.3667 & 4.1867 & 1.8467\end{array}$ $\begin{array}{lllllllllll}75 & 2.41 & 2.5 & 24 & 0.945 & 0.675 & 5.6767 & 3.48 & 7.2167 & 5.3867 & 2.03\end{array}$

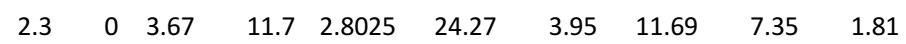
$\begin{array}{lllllllllll}2.9 & 0 & 3 & 14.383 & 3.0275 & 24.743 & 2.5433 & 16.68 & 8.6433 & 1.9267\end{array}$ $\begin{array}{lllllllllll}2.5 & 0 & 3 & 18.267 & 3.1167 & 19.14 & 5.78 & 14.533 & 8.5333 & 2.3767\end{array}$ $\begin{array}{rrrrrrrr}18 & 3.3167 & 1.3 & 10.807 & 4.38 & 12.9 & 6.3067 & 2.1033\end{array}$ $\begin{array}{rrrrrrrrr}0 & 25 & 0.7833 & 1.475 & 9.8267 & 3.77 & 8.1167 & 5.61 & 1.9\end{array}$ $\begin{array}{rrrrrrrrr}4 & 19.3 & 1.5167 & 1.55 & 16.133 & 7.2433 & 12.913 & 6.4733 & 2.14 \\ 4 & 15.7 & 1.9 & 1.875 & 11.74 & 4.68 & 10.77 & 6.7867 & 2.13\end{array}$ $\begin{array}{lllllllll}0 & 7 & 1.75 & 2.45 & 17.123 & 10.337 & 14.053 & 10.423 & 3.6067\end{array}$ $\begin{array}{rrrrrrrrr}5 & 11.3 & 2.9567 & 2.125 & 14.687 & 9.66 & 12.317 & 7.8633 & 2.7333 \\ 4 & 17.7 & 3.9083 & 1.8625 & 10.247 & 7.29 & 11.417 & 7.1967 & 2.6833\end{array}$ $\begin{array}{rrrrrrrrr}2.5 & 27.3 & 3.1 & 1.7125 & 14.913 & 10.973 & 12.837 & 6.7667 & 1.94\end{array}$ $\begin{array}{rrrrrrrrrr}8 & 0 & 7 & 9.3333 & 2.675 & 18.233 & 13.35 & 13.417 & 9.5933 & 2.62 \\ & 0 & 4.33 & 4.1333 & 2.85 & 21.34 & 17.14 & 11.223 & 8.61 & 1.49\end{array}$ 


\begin{tabular}{|c|c|c|c|c|c|c|c|c|c|c|c|c|c|c|c|c|}
\hline leef & 8301 & NA & NA & 47.4 & 4.3467 & 74.5 & 2.15 & 4 & 14 & 2.9375 & 1.685 & 10.567 & 5.0533 & 6.9067 & 4.595 & 1.705 \\
\hline Betancur & 8093 & -74.214 & 4.0873 & 33.5 & 4.7 & 79 & 3.3 & 2 & 14 & 2.07 & 2.2167 & 15.515 & 9.5 & 11.093 & 7.0467 & 1.43 \\
\hline ribe & 5537 & NA & NA & 30.25 & 605 & 105 & 2.4 & 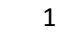 & 14 & 1.32 & .7025 & 17.71 & 915 & 2.137 & 6.14 & 1.325 \\
\hline Iribe & 4505 & NA & NA & 3.75 & 4.425 & 47.75 & 2.2 & 2 & 12.5 & 1.7067 & 1.925 & 12.915 & 9.1 & 11.743 & .2133 & 2.5233 \\
\hline arcia-Barriga & 17193 & NA & NA & .667 & 2.27 & 8.167 & 5667 & 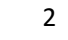 & 10.5 & 2.7417 & 1.91 & 11.53 & 7.57 & 13.067 & 7.2 & .9033 \\
\hline asas & 517 & NA & NA & 4.85 & 4.5 & 109 & 1.9 & 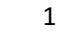 & 10.5 & 1.8575 & 1.7871 & 15.237 & 8.6 & 14.047 & 6.0467 & 2.17 \\
\hline arcia-Barriga & 8103 & NA & NA & 34.75 & 7.285 & 126 & 2.8 & 1 & 10 & 2.4467 & 2.1825 & 20.02 & 1.547 & 19.765 & 7.4933 & .7333 \\
\hline s et $\bar{c}$ & 25567 & NA & NA & 7.55 & 4.325 & 75 & 1.5 & 1 & 9 & 2.34 & 2.38 & 17.51 & 10.57 & 16.953 & 7.7767 & .6533 \\
\hline Iribe & 2473 & NA & NA & 41.5 & 6.595 & 60.5 & 1.7 & 1 & 10 & 4 & 2.1833 & 18.707 & 10.133 & 17.263 & 8.07 & 2.96 \\
\hline umbert et al. & 26849 & NA & NA & 46 & 7.06 & 79.5 & 1.6 & . & 6 & 5.3167 & 2.56 & 23.325 & 17.995 & 21.71 & 6.125 & 1.74 \\
\hline Barriga & 13390 & NA & NA & .167 & 4.5667 & 71 & 2.1 & 1 & 9 & 1.2 & 1.8833 & 11.7 & 8.76 & 12.617 & 7.795 & 2.55 \\
\hline arclay \& Juajib & 6137 & NA & NA & .533 & 3.7667 & 79 & 2.4 & 0 & 5 & 6.855 & 3.52 & 18.43 & 9.685 & 20.1 & 8.39 & 3.56 \\
\hline ern & 1486 & NA & NA & 38.9 & 3.2 & 70.5 & 3 & c & 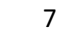 & 5.03 & 3.2 & 19.63 & 10.93 & 17.647 & 3333 & 2.95 \\
\hline Iribe & 6786 & NA & NA & 0.333 & 2567 & 74 & 2.2 & 0 & 5 & 4.12 & 2.5467 & 24.76 & 16.48 & 16.84 & 9.74 & 2.92 \\
\hline arclay et al. & 3258 & NA & NA & 39 & 4.33 & 68 & 2.6 & 0 & 4.5 & 5.45 & 2.4833 & 18.51 & 11.18 & 12.007 & 8.8433 & 3.09 \\
\hline t al. & 26904 & NA & NA & 133 & 4.87 & 79.2 & 2.6 & 0 & 5 & 5.32 & 2.735 & 20.67 & 11.27 & 11.125 & 7.865 & 2.565 \\
\hline ugang & 2965 & NA & NA & 35.5 & 4.2533 & 60.6 & 2.1 & 0 & 5 & 3.655 & 3.5 & 20.885 & 11.72 & 13.077 & 8.2467 & 2.6733 \\
\hline $\operatorname{arc}$ & 392 & NA & NA & 38.35 & 4.91 & 68 & 2.1 & c & 5 & 6467 & 2.45 & 23.4 & 9.89 & 1.4 & 1733 & 3.405 \\
\hline Cleef & 1575 & NA & NA & 40.95 & 3.5 & 60.5 & 2.5 & 0 & 3 & 7.22 & 3.2067 & 28.84 & 5.33 & 17.757 & 9.42 & 2.99 \\
\hline leef & 1573 & NA & NA & 37.6 & 3.1 & 45 & 1.8 & 0 & 3 & 8.1 & 3.185 & 18.33 & 8.55 & 13.1 & 7.94 & 2.5567 \\
\hline iaz & 2873 & NA & NA & 9.433 & 3.51 & 65 & 2.6 & 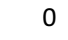 & 3 & 18 & 2.99 & 2.18 & 6.04 & 15.457 & 8.44 & .8067 \\
\hline Uribe & 7033 & NA & NA & 30.5 & 2.95 & 51.167 & 1667 & 0 & 3 & 7.115 & 3.115 & 20.513 & 5.5533 & 14.857 & 8.5033 & 1.69 \\
\hline \& Ji & 28785 & NA & NA & 38.4 & 3.24 & 53 & 2.1 & r & 3 & 12.76 & 3.365 & 17.94 & 8.15 & 15 & 10.64 & 1.585 \\
\hline Cuatrecasas \& Ji & 28789 & NA & NA & 38 & 4.05 & 63 & 2 & 0 & 3 & 6.6 & 2.85 & 21.79 & 8.42 & 13.427 & 8.9033 & 1.7733 \\
\hline arriga & 8117 & NA & NA & .167 & 4.38 & 667 & 1.9 & 0 & 67 & 2567 & 2.5825 & 25.967 & 11.287 & 13.58 & 9.4533 & 3.47 \\
\hline laramill & 6895 & NA & NA & .433 & 4.5933 & 54.3 & 2.9 & 0 & 3 & 10.35 & 3.7133 & 18.04 & 7.015 & 15.79 & 9.19 & 1.7567 \\
\hline Cuatrecasas & $9527 \mathrm{~A}$ & NA & NA & 25.95 & 5.195 & 106 & 1.4 & 3 & 8 & 2.1967 & 1.7275 & 11.64 & 6.09 & 10.277 & 5.8733 & 2.4033 \\
\hline Cuatrecasas & 9527 & NA & NA & .233 & 7.89 & 100 & 2.6 & 1 & 26 & 3.0433 & 1.58 & 12.52 & 7 & 11.347 & 6.0033 & 2.3633 \\
\hline sas \& Ji & 25908 & NA & NA & 42 & 4.4167 & 69 & 1.95 & 3.5 & 9 & 1.45 & 2.49 & 13.56 & 8.22 & 1.46 & 8.06 & 2.755 \\
\hline LATP & 10 & NA & NA & .167 & 5.2333 & 333 & 2.3 & 0 & 15.3 & 2.37 & 2.0914 & 13.86 & 5.1433 & 7.3833 & 6.6433 & 2.51 \\
\hline LATP & & NA & NA & .667 & 5.3667 & 95 & 2.45 & 0 & 15.7 & 2.072 & 1.79 & 14.08 & 1367 & 8.0167 & 6.5967 & 2.34 \\
\hline LATP & & NA & NA & .167 & 4.9 & 96 & 2.2 & 0 & 27 & 1.515 & 1.5973 & 9.0533 & 4.1 & .0167 & 4.6067 & 1.9633 \\
\hline LATP & 11 & NA & NA & .333 & 5.4667 & 111 & 667 & 0 & 23.7 & 1.8817 & 1.405 & 10.28 & 5733 & 7.12 & 5.61 & 1.53 \\
\hline avid & 823 & NA & NA & 267 & 3.8667 & 74 & 2.4333 & 0 & 5.67 & 11.138 & 2.5025 & 19.62 & 11.297 & 15.07 & 9.7367 & 2.5833 \\
\hline David & 812 & NA & NA & 8.967 & 3.5 & 533 & 3.2 & 0 & 7.67 & 2.43 & 2.7675 & 5.167 & 15.413 & 15.58 & 9.05 & 2.3867 \\
\hline ivid & 808 & NA & NA & 47.7 & 3.7333 & 92 & 2.4 & 0 & 7 & 2.87 & 2.0275 & 19.723 & 12.283 & 14.833 & 10.163 & 2.45 \\
\hline David & 825 & NA & NA & 39 & 3.1733 & 667 & 5667 & 0 & 5 & 3.885 & 2.3325 & 17.75 & 1.373 & 17.2 & 9.6567 & 3.0967 \\
\hline os David & 822 & NA & NA & .767 & 3.5 & 66 & 3 & 0 & 5 & 10.75 & 3.3633 & 22.8 & 13.6 & 16.983 & 10.153 & .8733 \\
\hline avid & 819 & NA & NA & 333 & 6733 & 57 & 667 & 0 & 3.33 & 6.222 & 2.67 & 20.7 & 11.37 & 8.8767 & 8.4933 & 2.77 \\
\hline JLMA & 1 & NA & NA & 3.867 & 2.9 & 84.667 & 1.8667 & 3.67 & 17 & 1.053 & 6825 & 10.847 & 5.3 & 8.97 & 6.1867 & 1.6567 \\
\hline LATP & 7 & -74.1 & 4.22 & 30.2 & 3.4 & 82.633 & 1667 & 4 & 21.7 & 2.7433 & 1.5075 & 12.237 & 5.5567 & 9.9933 & 7.2067 & 0.92 \\
\hline s David & 811 & NA & NA & 32 & 3.6667 & 63.167 & 1.2 & 1.33 & 7 & 1.302 & 1.2403 & 12.037 & 5.2067 & 10.553 & 6.0367 & 1967 \\
\hline s David & 14 & -74.166 & 4.4941 & .667 & 2.8333 & 88 & 1.5 & 2 & 9 & 1.0367 & 1.63 & 12.415 & 6.985 & 10.923 & 6.89 & 1.79 \\
\hline SAV & 1 & -74.1 & 4.44 & 30.3 & 4.4667 & 99 & 1.95 & 2 & 15 & 1.605 & 1.1675 & 7.605 & 3.96 & .19 & 6.48 & 1.4067 \\
\hline Gran & 824 & -74.232 & 4.2355 & 20.667 & 3.7333 & 3.75 & 1.6 & 1 & 14.5 & 1.118 & 1.6025 & 4.9433 & 8967 & 11.097 & 5.39 & 1.1733 \\
\hline LATP & 8 & -74.165 & 4.2077 & 34.567 & 2.9667 & 74.3 & 2.1 & 3 & 18.3 & 2.075 & 1.6275 & 12.297 & 8.17 & 12.347 & 7.5467 & 2.63 \\
\hline Granados David8 & _S152 & NA & NA & 30.8 & 3.9333 & 79 & .9667 & 3 & 12.3 & 6.4 & 1.435 & 12.277 & 5.5833 & 10.04 & 7.3233 & 2.9367 \\
\hline Granados David & 840 & -74.345 & 3.9193 & 5.833 & 1.7333 & 71.5 & 2.15 & 4 & 44 & .205 & 1.1875 & 4.9433 & 3.1133 & 6.4067 & .0033 & 1.7933 \\
\hline avid & 837 & -74.308 & 4.0547 & 39.1 & 7.1333 & 91.533 & 3667 & 0 & 21.7 & 2.895 & 1.6825 & 13.537 & 6.11 & 8.4367 & 7.44 & 2.3733 \\
\hline Granados David & 833 & -74.414 & 3.8751 & 3.733 & 5.2333 & 80.933 & 2.9 & 1 & 19.7 & 1375 & 1.36 & 9.6633 & 3.46 & 8.2767 & 6.5933 & 2.4833 \\
\hline s David & 841 & -74.338 & 3.9479 & 41.4 & 5.4333 & 71.2 & 3 & 2 & 17 & 3.49 & 1.6875 & 17.07 & .9933 & 13.063 & 10.063 & 4.18 \\
\hline Granados David & 832 & -74.428 & 3.7872 & 667 & 6.3667 & 63 & 2 & 1 & 19.5 & 1.0033 & 1.385 & 8.7433 & 2.5433 & 6.7767 & 5.315 & 2.55 \\
\hline Granados David & 842 & -74.335 & 3.948 & 41.267 & 4.4333 & 89.7 & 2.6 & 0 & 24.3 & 1.28 & 1.5375 & 12.5 & 3.7433 & 6.7133 & 5.8033 & .7367 \\
\hline os David & 831 & -74.394 & 3.9014 & 45.9 & 8.1667 & 0.25 & 3.65 & 3 & 18 & 1.8017 & 1.6575 & 16.3 & 10.167 & 10.87 & 7.5933 & 2.4 \\
\hline Granados David & 835 & NA & NA & 3.067 & 8.1 & 90 & 3.35 & 1.5 & 19 & 5.03 & 1.8875 & 21.847 & 12.957 & 11.773 & .1433 & 3.38 \\
\hline David & 834 & NA & NA & .767 & 7.1667 & 92 & 3.4 & 3 & 12 & 4.87 & 1.8225 & 16.853 & 7.47 & 14.197 & 8.9933 & 3.1733 \\
\hline Granados David & 846 & NA & NA & 0.667 & 10.4 & 70.5 & 333 & 33 & 11 & 3.7067 & 2.06 & 14.54 & .7433 & 13.98 & 7.7267 & 1.71 \\
\hline Granados David & 845 & NA & NA & 38.133 & 3.7 & 68.9 & 1.7 & 0 & 5 & 3.1667 & 1.7875 & 16.64 & 9.86 & 13.73 & 7.5633 & 2.73 \\
\hline Granados David8 & S84 & NA & NA & 0.433 & .9333 & 69 & 3.5 & 0 & 9 & 3.5667 & 2.9275 & 26.013 & 18.66 & 15.14 & 9.5067 & .5867 \\
\hline Granados David & 856 & NA & NA & 27.833 & 3.09 & 56 & 2.3 & 1 & 12 & 2.26 & 1.545 & 10.037 & 5.1367 & 9.5633 & 6.9933 & 1.59 \\
\hline
\end{tabular}

